\title{
The Forms of Plurality According to Al-Halabi in The Book Omdat Al-Hifaz Fi Tafseer Ashraf Al-Al Fadh
}

\author{
Dlawar Jawhar Ahmed ${ }^{1}$, Ziad Abdullah Abdulsamad*2 \\ ${ }^{1}$ Arabic department, Faculty of Arts, Soran University, Erbil, Iraq \\ ${ }^{2}$ Arabic department, Collage of education, Salahaddin University, Erbil, Iraq \\ dr.zyadalbanna@gmail.com
}

\begin{abstract}
:
Morphological thought appeared at Al-Halabi clearly and clearly in its origination of the singular in his book (Omdat al-Hifaz fi Tafseer Ashraf al-Al Fadh), which deals with the vocabulary of this lexical book, noting in his analysis the different morphological formulas mentioned in the words and the connotations that distinguish one use from another, and from the buildings The morphology that he mentioned and detailed in it the buildings of the multitude of multitudes, mentioning the standard ones, and what are memorized and not measured by these multitudes, and here we single out in these pages a group of Al-Halabi's morphological references to the buildings of the multitude of multitudes and the meanings and connotations given to these formulas in a paper entitled (The form of plurality According to $\mathrm{Al}$ - Halabi in the book Omdat Al - Hifadh fi Tafsir Ashraf Al - Alfadh).
\end{abstract}

Keywords: Al-Halabi; Al-Omda; Plurality's Forms; Al-Wazn.

Crossref doi https://doi.org/10.51345/.v31i2.279.g166 


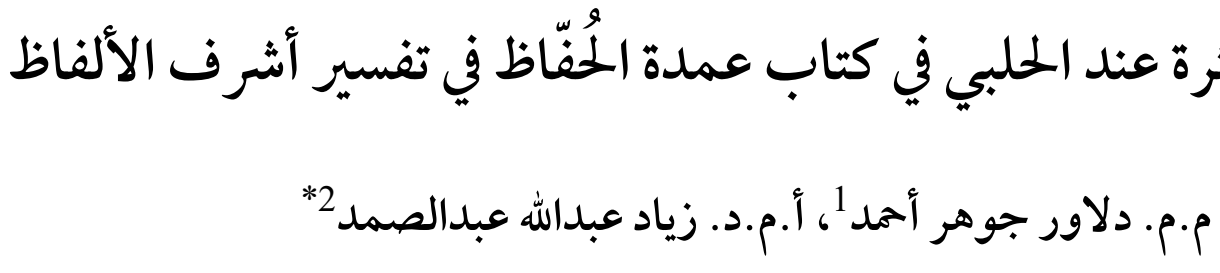$$
1 \text { ق إمسم اللغة العربية، كلية الآداب، جامعة سوران، أربيل، العراق }
$$$$
2 \text { قسم اللغة العربية،كلية التربية، جامعة صلاح الدين، أربيل، العراق تصدية }
$$ \\ dr.zyadalbanna@gmail.com}

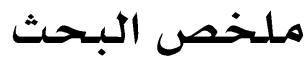

ظهر الفكر الصرفي عند الحلبيّ جلياً واضحاً في تأصيله للمفردة في كتابه (عمدة الحفاظ في تفسير أشرف الألفاظ)، وهو يعالج مفردات هذا الكتاب المعجمي، منبّهاً في تحليله إلى اختلاف الصيغ الصرفية التي وردت في الألفاظ وما تؤديها من دلالات تيّز

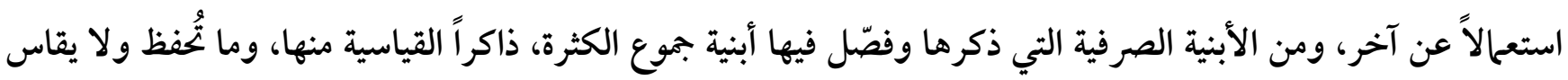
عليها من هذه الجموع، وهنا نُفرد في هذه الصفحات بجموعة من الالتفاتات الصرفية للحلبيّ لأبنية جموع الكثرة وما أولت من معانٍ ودلالات لهذه الصيغ في بحث معنون بـ (أبنية بموع الكثرة عند الحلبيّ في كتاب عمدة الحفاظ في تفسير أشرف الألفاظ). 
المقدمة

الحمد لله رب العالمين، والصلاة والسلام على رسول الله الأمين، وعلى آله وصحبه الطيبين الطاهرين، وبعد: فقد أولى دارسو لغة القران القر آن الكريم اهتحاماً كبيراً، بدراسة أصو اته وأبنيته و ألفاظه وتر اكيبه، وكيفية نطقه وإجادته والوقوف عند معانيه ومعرفة وصله وقطعه، كلّ ذلك لامتثال أوامره والانتهاء عن نو اهيه، فإن المرء لا يسعه القيام بحا يُملى عليه إلا بعد فهم المطلوب منه و العلم به، قال تعالى خخاطباً نبيه المصطفى وأمته من

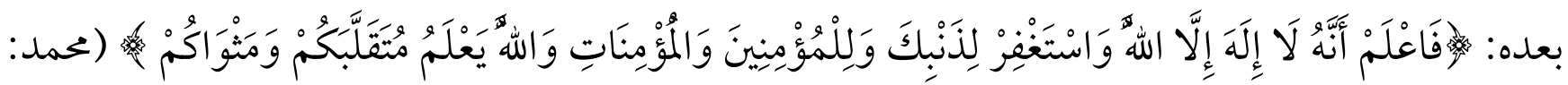

ومن العلماء الذين خدموا كتاب الله تعالى وأبلوا بلاء حسناً في ذلك السمين الحلبيّ (ت 56 هـ)، فقد ألّف الكثير من المؤلفات التي مهذّت الطريق للقرّاء في فهم كتاب الله تعالى والتقرّب إليه سبحانه، وكان لعلمه الواسع وإدراكه العميق أثر كبير في بلورة المضامين القرآنية، منطلقاً من الفهم اللغوي لكتاب الله تعالى في تفسير ألفاظه ودلالات تر اكيبه، وكان الدرس الصرفي مسلكاً من مسالكه للوصول إلى ثمار هذا البستان الثرّ. ظهر الفكر الصرفي عند الحلبّ جلياً واضحاً في تأصيله للمفردة في كتابه (عمدة الحفاظ في تفسير أشرف الألفاظ)، وهو يعالج مفردات هذا الكتاب المعجمي، منبهاً إلى اختلاف الصيغ الصرفية التي وردت في الألفاظ وما تؤديها من دلالات تميّز استعالاً عن آخر، ومن الأبنية الصرفية التي ذكرها وفصّل فيها أبنية الكثرة، ذاكراً القياسية منها، وما ثُّفظ ولا تُقاس عليها، وهنا نُفرد في هذه الصفحات على ثلاثَة مطالب بموعة من الالتفاتات الصرفية للحلبيّ لأبنية جموع الكثرة في بحث عنو انه بـ (أبنية جموع الكثرة عند الحلبيّ في عمدة الحفاظ في تفسير أشرف الألفاظ). 


\section{المطلب الأولَّل: مفهوم الجهمع}

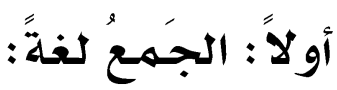

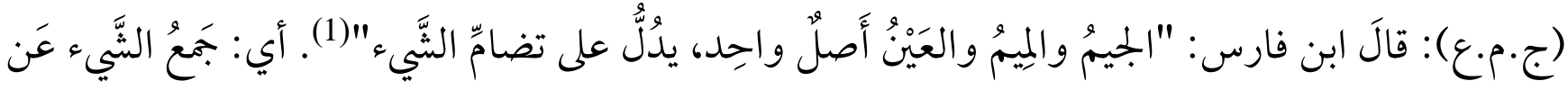

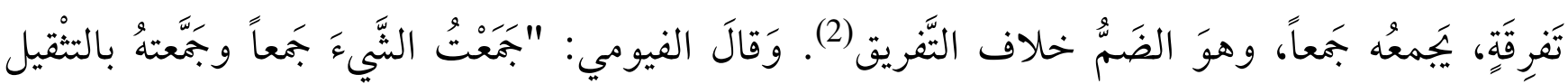

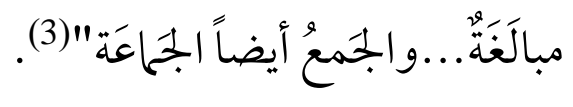

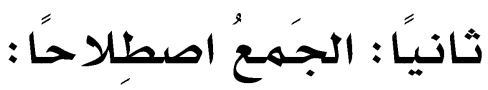

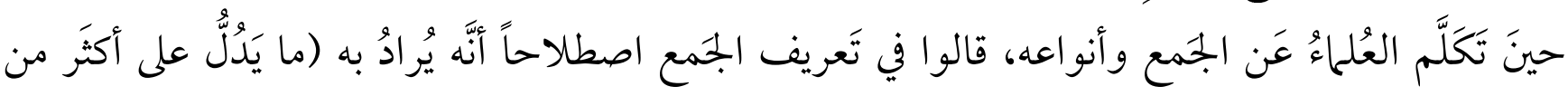

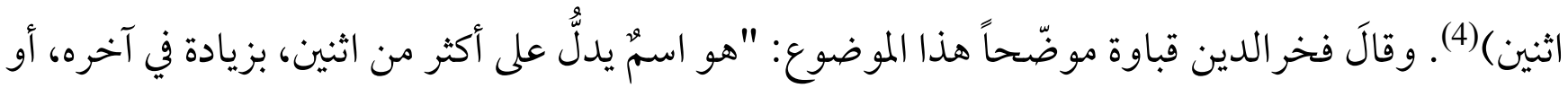

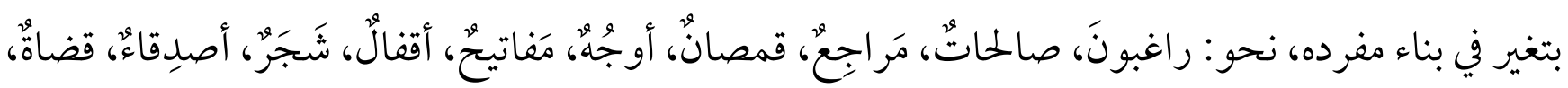

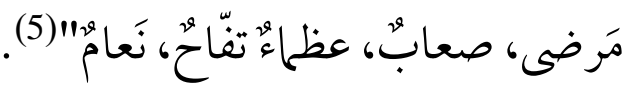
والجَمعُ بصورة عامة -كما ورد في كتب النحويين واللغوين - نوعان، الأوَّل: الجَمعُ السّالمُ. والثّاني: جَعُ التكسير. وجمع التكسير على أنواع عديدة، وما يُراد به في هذا البحث هو: (جَعُع الكثرة) من ضمن جموع

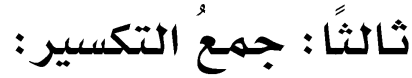

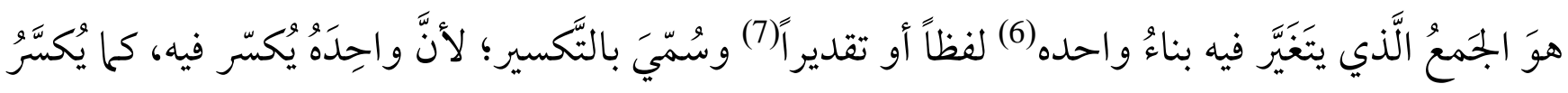




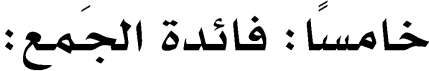

وللجمع دلالات وأهمية كثيرة، سيأتي ذكرها فيا بعد، ولكن أحد الجموانب البارز فيه هو : أنَّك إذا تحدَّثتَّ عن

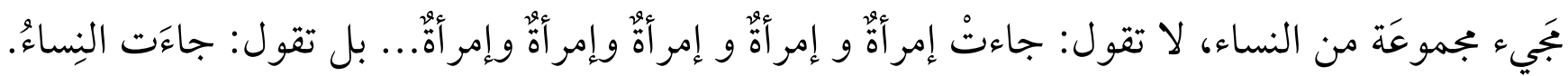
وهذا يُعدّ من الإقتصاد اللغوي.

المطلب الثّاني: أوزان أبنية جموع الكثرة عند الصرفيين:

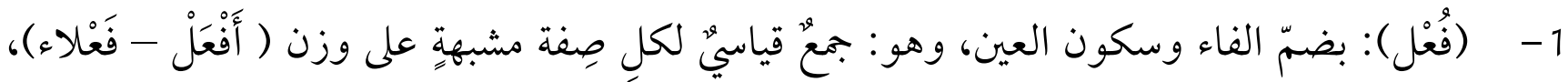

$$
\text { نحو: (أَضْفَر - صَفْرَاء) على (صُفْر) (9). }
$$

2- - (فُعُل): بضمّ الفاء والعين، ويُجمع عليه ماكان وَصفاً على وزن (فَعول)، نحو: (غَفور - على غُفْر) ). وكلّ اسم رباعي قبلَ حرفه الأخير حرفُ مدّ، ولامه صحيحة، ويشترط أن تكون غير مضاعفة، إذا كانت المدّة ألفاً، وغير مختوم بتاء التأنيث، مثل: (قَضيب) على (قُضُب) اسم رباعي قبل حرفه الأخير ياء)

3 - صيغة (فُعُول): يطّرد في كل اسم ثلاثي على الأوزان التالية: (فَعِل)، نحو: (كَبد - كُبوّود). و و(فَفْل)،

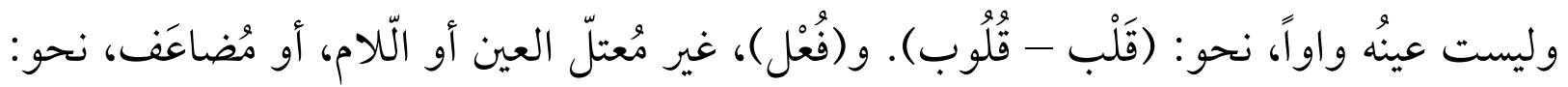

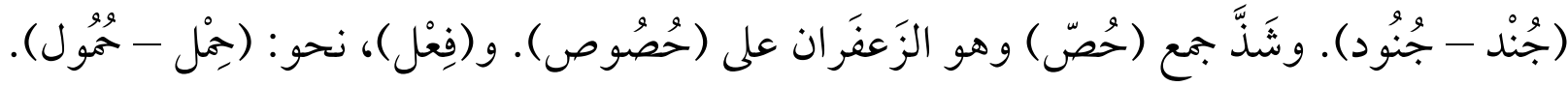

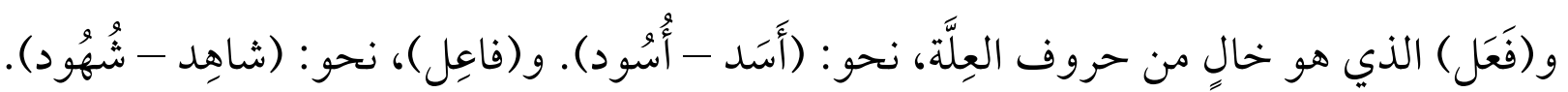

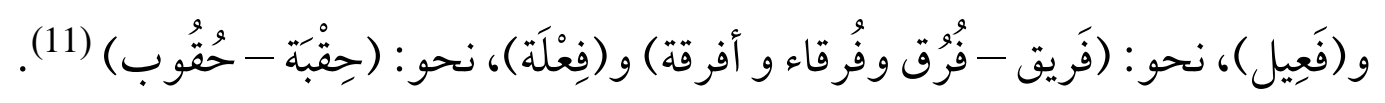

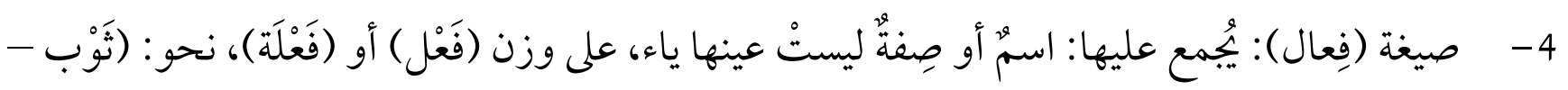
ثِياب). ومن النادر صياغته من معتّل العين، نحو: (ضَيْعَة - ضِياع) و (ضَيْف - ضِياف). واسم على وزن (فُعْل) ليستْ عينه واواً، ولا لامه ياءَ، نحو: (رُمْح -رِماح)، و (رِيح -رِياح). واسمُ على وزن (فِعْل)، نحو: (ظِلّ - ظِلال)، و (ذِيْبَ - ذِئاب). واسمّ صحيح اللام، غير مُضاعف، على وزن 


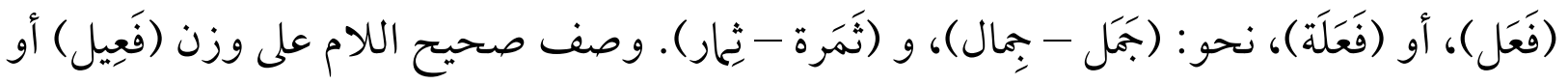

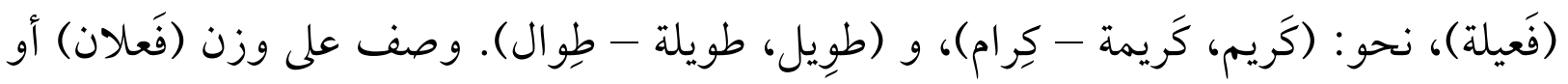

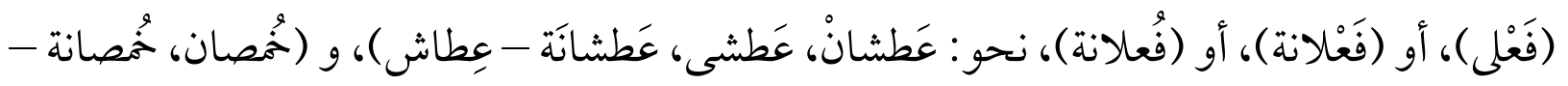
حَماص). وقد جَمَعوا على هذا الوزن على غير قِياس (راعٍ، راعية - مِعاء)، و (قائم، قائِمة - قِيام)،

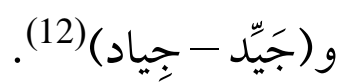

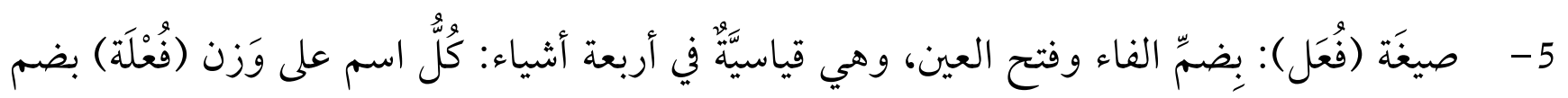

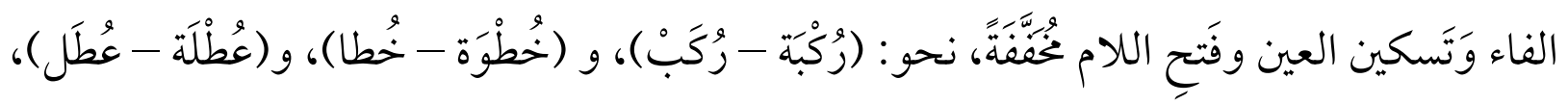

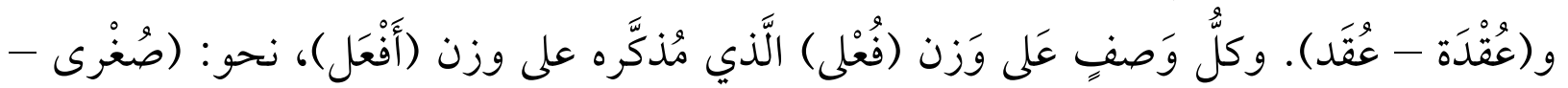

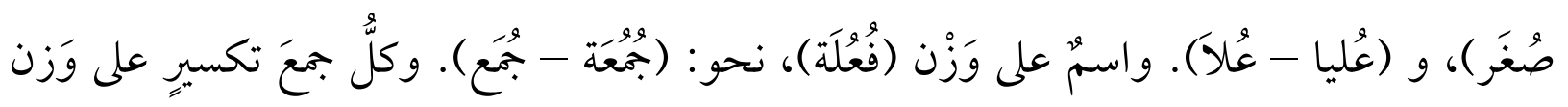

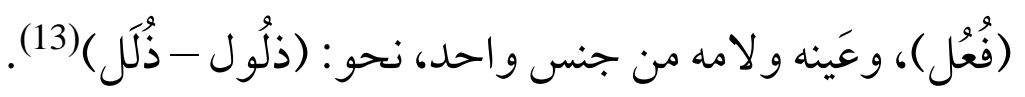

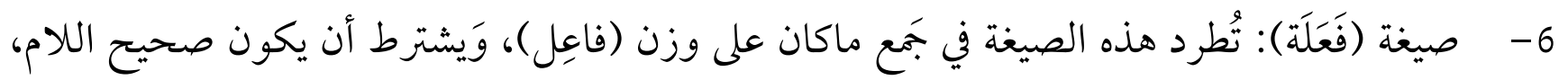

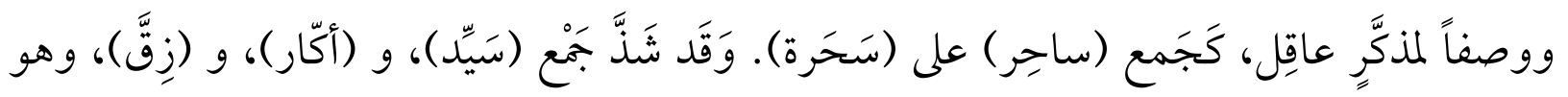

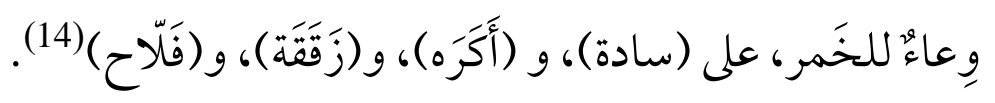

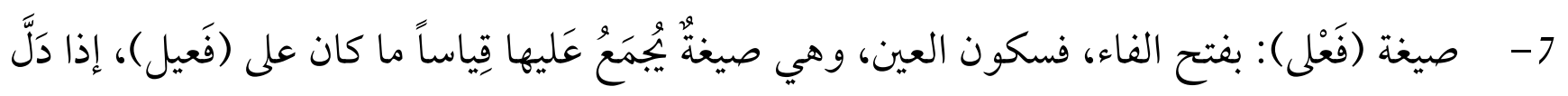

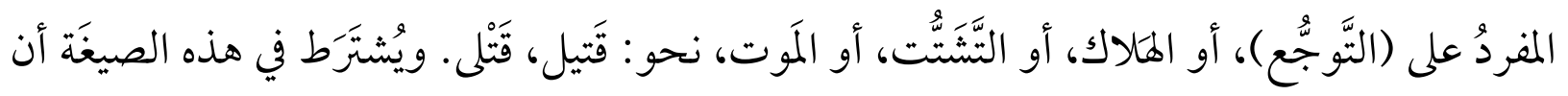

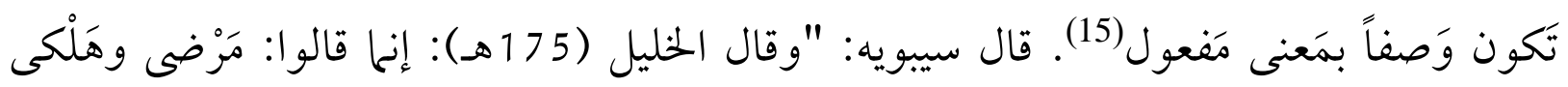

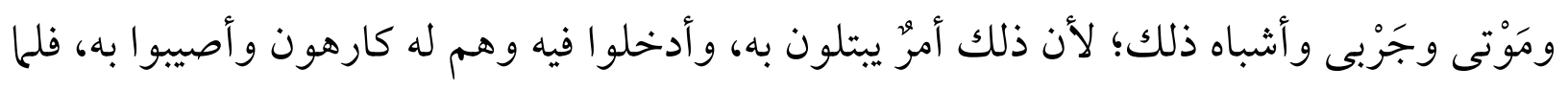

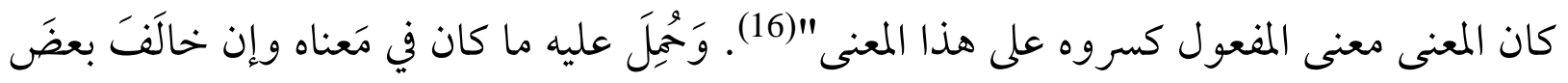

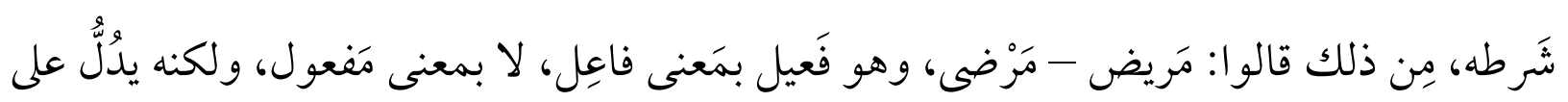

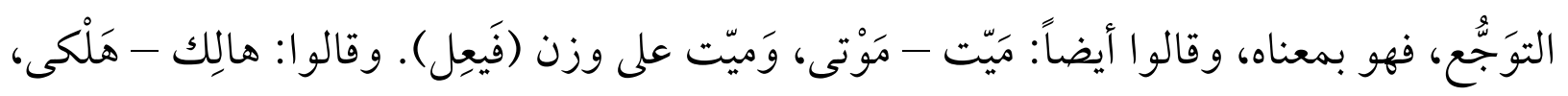




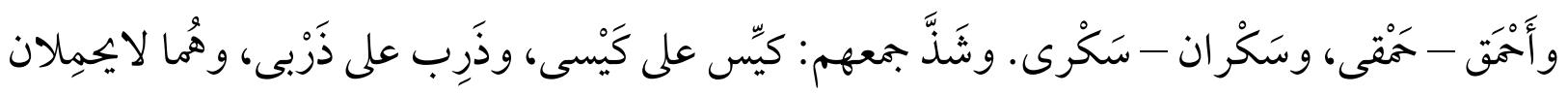
المعاني السابقَة (17). وكَّس وذَرِبَ مَعناهمان(18).

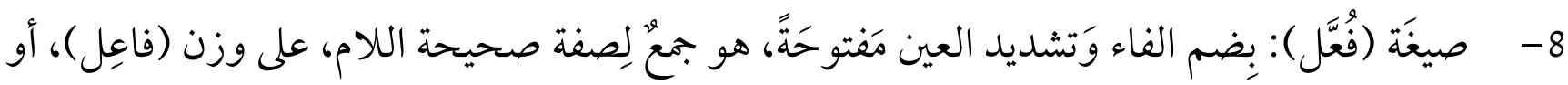
(فاعِلة)، نحو: (راكِع، راكِعة - رورَّع ). ومن النادر أن يكون من معتل اللام، نحو: (غازٍ - غُوَّى).

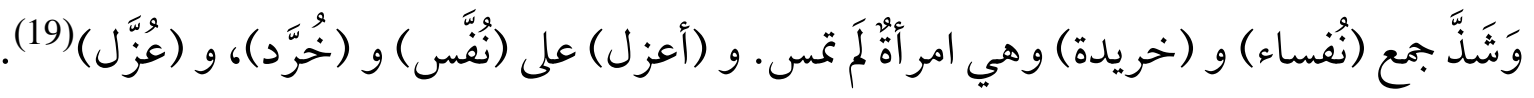
9- صيغَة (فِعْلان): بكَسر الفاءِ فسكون العين. ويطرد أيضًا في أربعة: اسم على "فُعال" كغلام وغراب، على غِلمان وغِربان. وعلى "فُعَل" كصُرَد وجُرَذَ، على صِردان و جِردان. و "فَقَل " كتاج على تِيجان، ونار على نيران؛ لأنَّ الألف فيها أصلها واو. وفُعْل" بضم أوله وسكون ثانيه؛ حال كونه "واوي العين، ك: حوت" وحيتان، "وكوز" وكيزان. وقل في نحو: صِنو وخِرْب وغَزَال، وِِوار وحائِط، وظَلِيم وخَرِوف (20). 10 - صيغَة (فُعْلان): يَنقاس هذا الوَزن في ثلاثة أوزان للاسم المفرد، وهي: فَعْل : نحو: (ظَهْر - ظُهران)، و (بَطْن - بُطنان). وفَعَل : نحو: (جَمَل - جُملان)، و (ذَكَرَ - ذُكران)، و (بَلَد - بُلدان)، و (حَمَل مُملان). و لأبََّّ للوزن أن يكونَ صَحيح العين. وفَعِيل : نحو: (رَغِيف - رُغْفان)، و(كَثِب - كُثبّان).

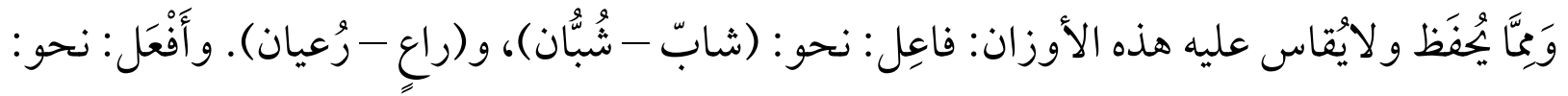
(أَسوَد - سودوان)، و (أَعمى - عُميان). وفِعال: نحو: (جِدار - جُدران). وفُعال: نحو: (زُققاق زُقَّان)، و وحُوار - ولد الناقة- - حُوران)(21).

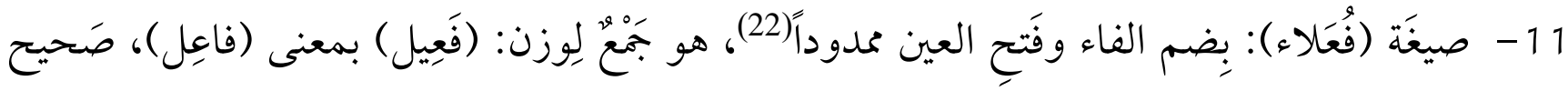
اللام، غير مضاعَف، دالّ على سجيّة مدح، أو ذَّم، نحو: (ظَريف - ظُرَفاء)، و (بَخِِل - بُخَلاء)، أو وصفُ لمذكَّر عاقِل على وَزن (فاعِل) دالّ على سجيّة مدح، أو ذَم، نحو: (عالمِ - عُلَّم)،)، و(جاهِل -

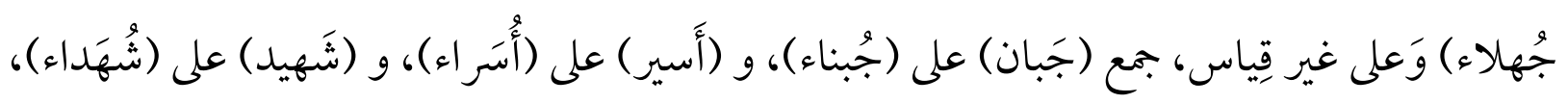
و (نَذل) على (نُذلاء)، و (صِهر ) على (صُهر اء)، و (ناظِر ) على (نُظراء)، و (قَتَيل) على (قُتَلاء) (23). 


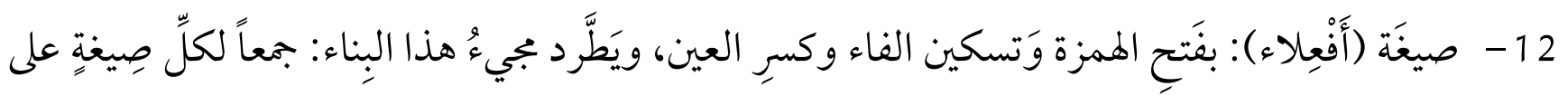

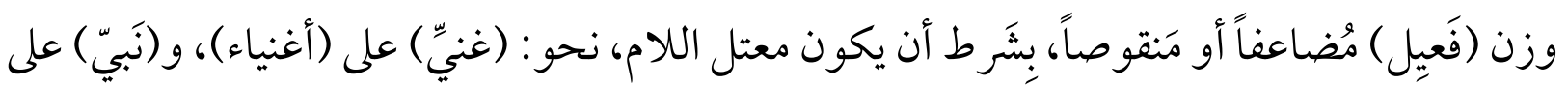

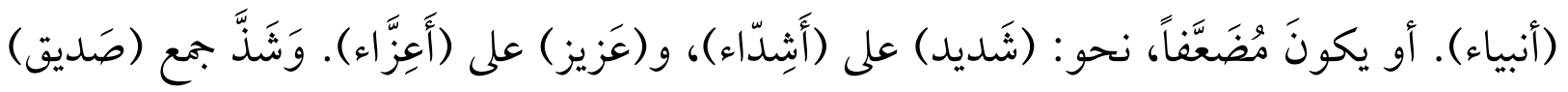

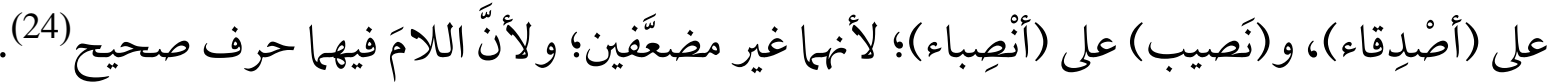

\section{المطلب الثالث: أبنية جموع الكَثرة عندَ الحَلَبيّ}

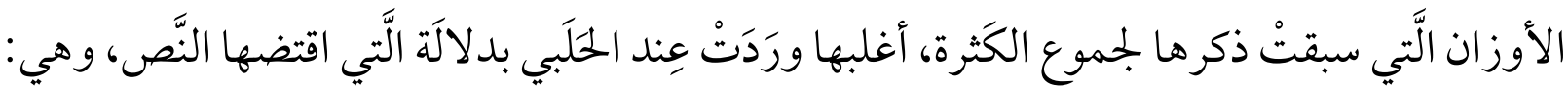

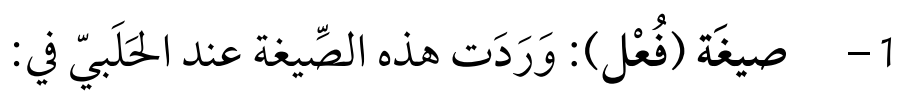

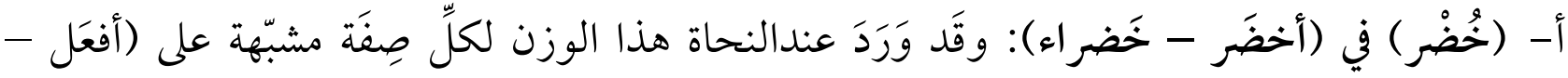

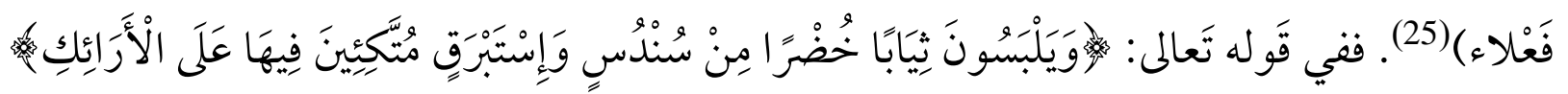

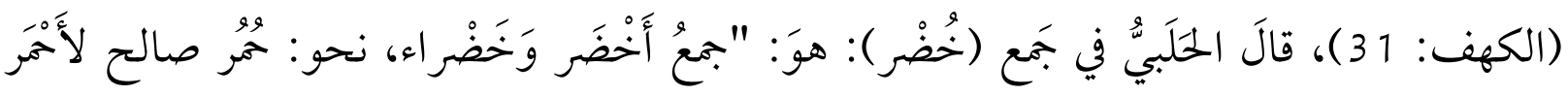

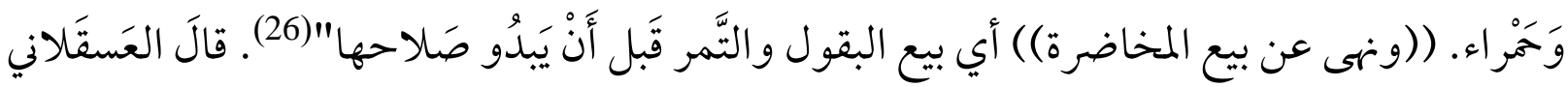

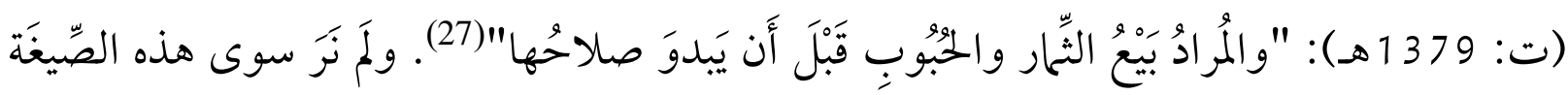

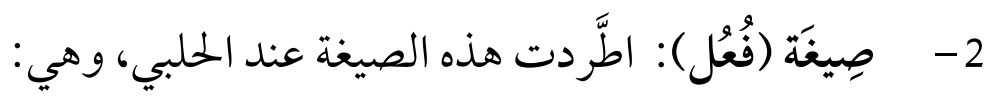

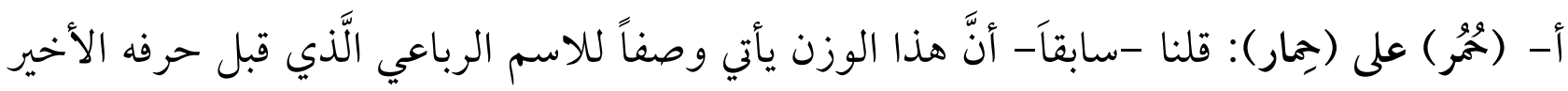

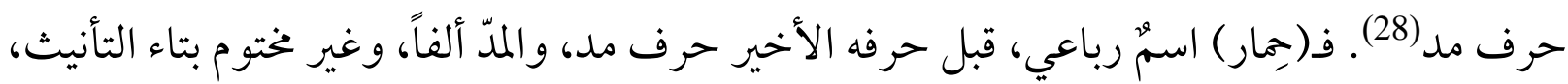

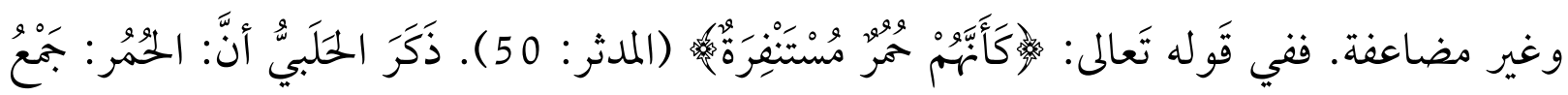

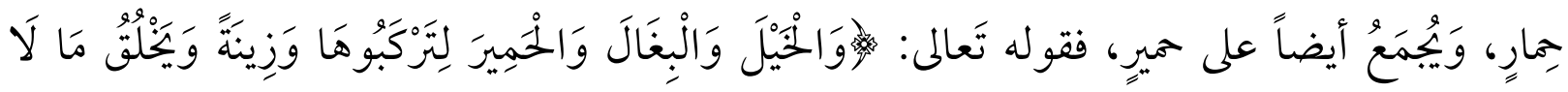

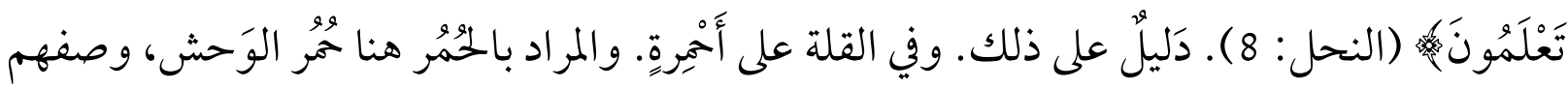
بعظم القوة)(29). ويشبهرم بالحمر الوحشية المذعورة حين فرّوا من القرآن وكذبوا به، وهو إثبات 


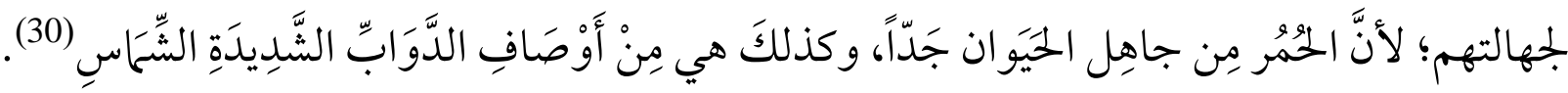
والدلالة الو اضحة في هذه الآية هي: أنه فرَّق بالجمع بين (الحُمُر ) و (الحمير) بمعنى الأول للوحوش، و الثاني لغيرها. - - صيغة (فُعُول): وما ورد عند الحلبي على هذا الوزن، هو:

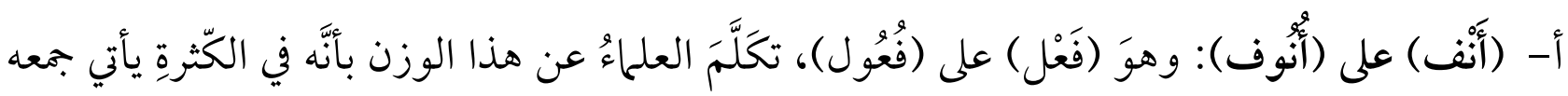

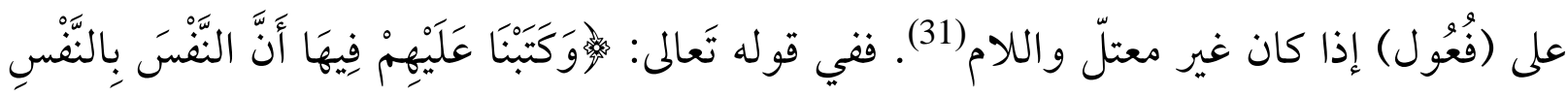

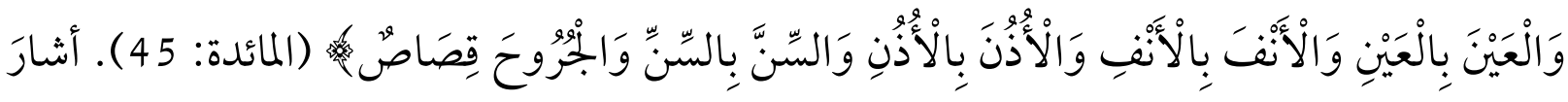
الحَلبيُّ إلى قرائين في (الأنف)، وهما: (النصب والرفع. والأنف كائن ومأخوذ بالأنف، وفيه غير ذلك. ويجمع على آنفٍ في القلة وأُنوفٍِ في الكثرة(32). فالقِراءة بالرَّفع للكسائي، والنَّصب لباقي القَّرَاء(33). وقَد يُقال في جمع الأنْف (الأنافي) وهذا غلط عندهم، والصحيح في الكثرة (الأُّوف) (34). بَ- (جِذْع) على (جُذُوع): وَرَدَت هذه الصِّيغَة بدلالَة (الجَمع) في (العُمَدة)، حينَ فَسَّرَ الحَلَبِّ قَوله تَعالى:

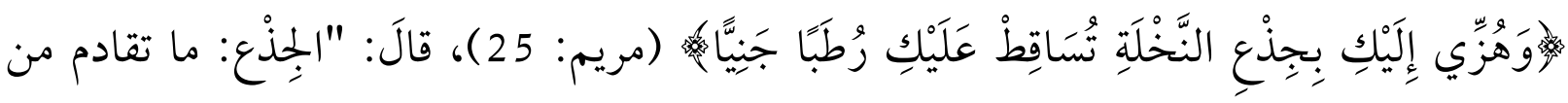
خشب النخل وغلب فيما بينها، ولذلك جعل آية لمريم عليها السلام في قوله: (وهزي إليك بجذع

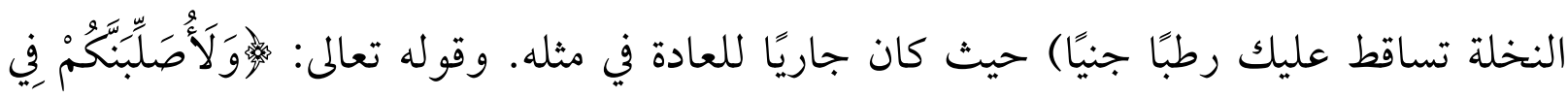
جُذُوعِ النَّخْلِ (طه: 1 7)، يريد: في أخس ما يكون من النخل لهوانكم علينا، فلا نشغل بكم فيه منفعة من النخل المثمر وبالغ بأن جعل الجذوع ظروفًا لهم... ويقال للدهر: جَذْع، تشبيهًا بالأَحداثِ

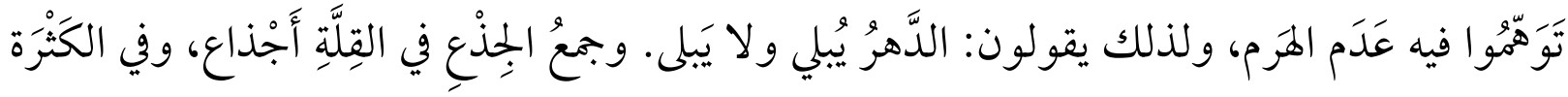
جُذوع. ولذلك أوثر في القرآن ليَهول عليهم ما توعدهم"(35). فجمعُ الكثرة في الآية السابقة وردَ نَّ تهديداً عند بجيء اليوم الموعود.

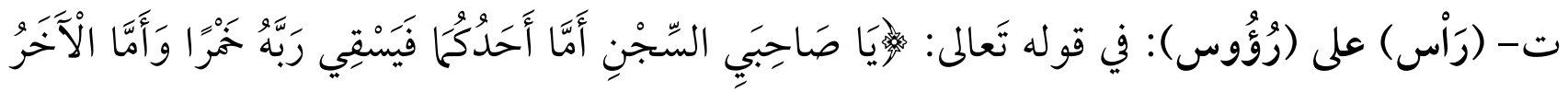

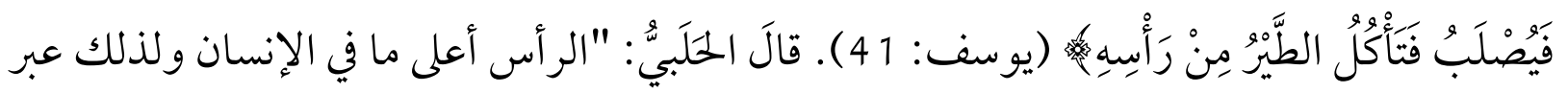


بها عن كل عالٍ فقيل: رأس الجبل. ويعبر بها عن أول الشيء، ومنه: رأس الحول. وقيل للسيد رأس القوم لذلك، ومنه رجل رئيس، ورأسه من ذلك. ويممع الرأس على رؤوسٍ في الكثرة وأرؤسٍِ في

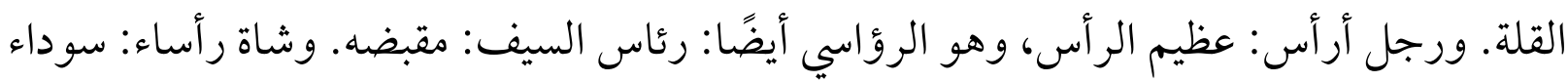

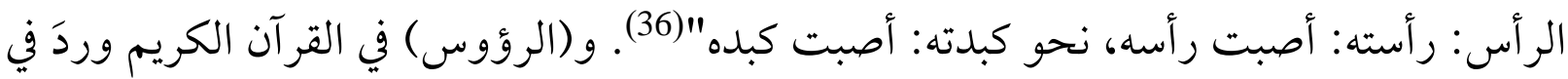
صيغة تشبيه شَنْع وقبيح، وهو نوعُ من النبات، وبها أنَّا لمَنَر رؤوس الشياطين، لكن هذا التشبيه فيه

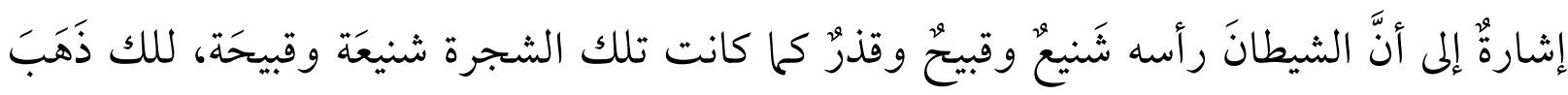

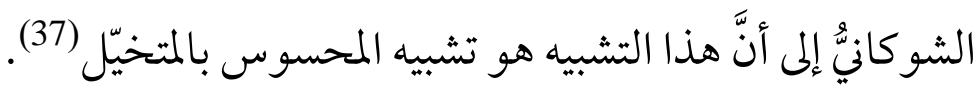

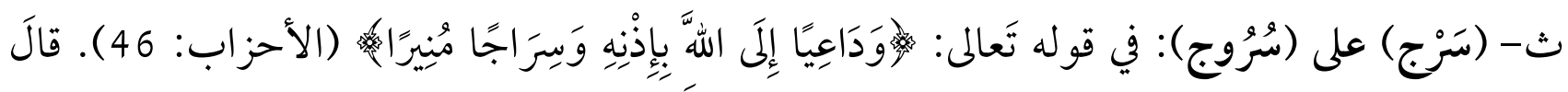

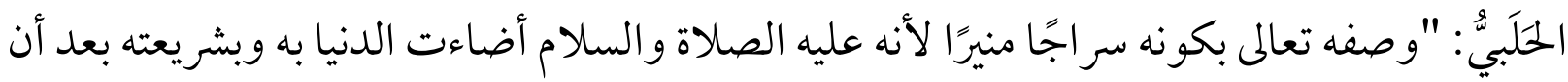

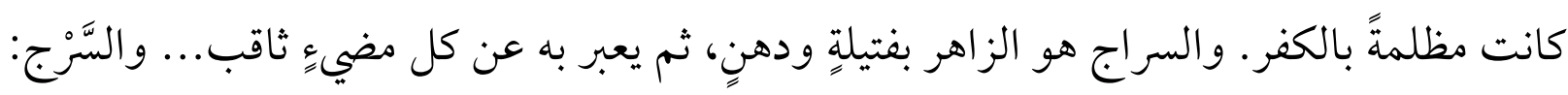
رحالة الدابة، و السراج: صانعه، والجمع سروجٌ وأسرجّ كفلوسِ وأفلسٍ كثرةً وقلة" (38). 4- صيغَة (فِعال): وما رود عند الحلبي على هذا الوزن، هو:

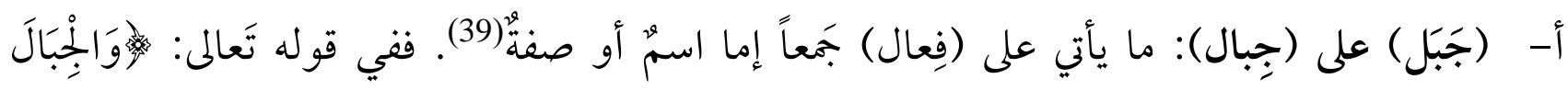

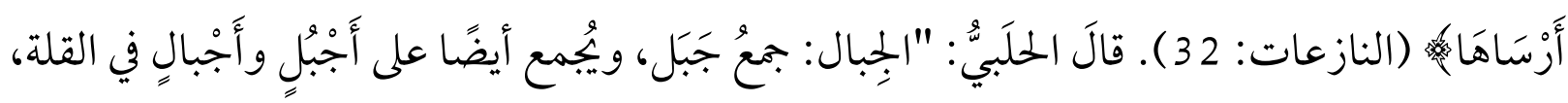

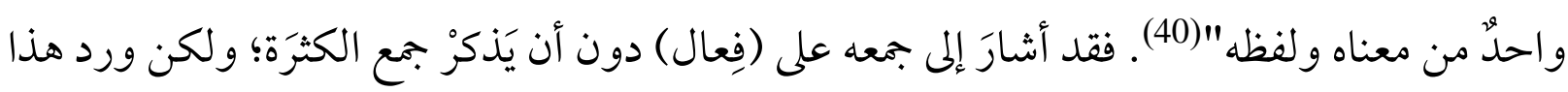

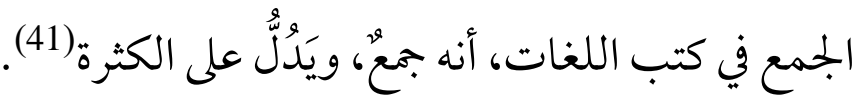

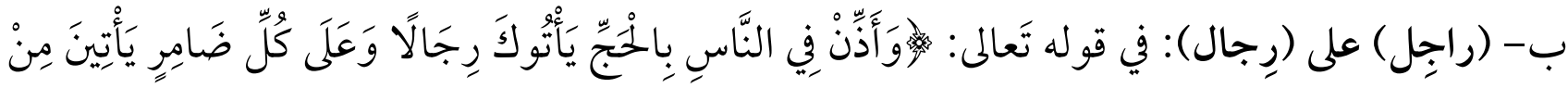

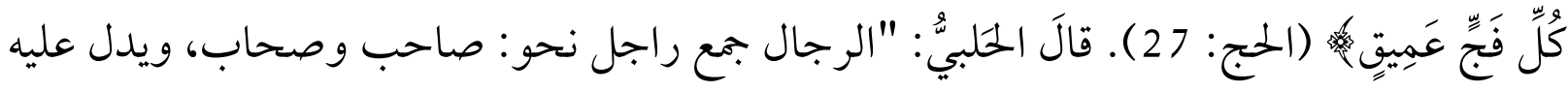

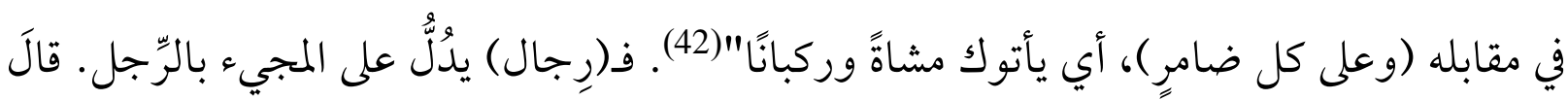

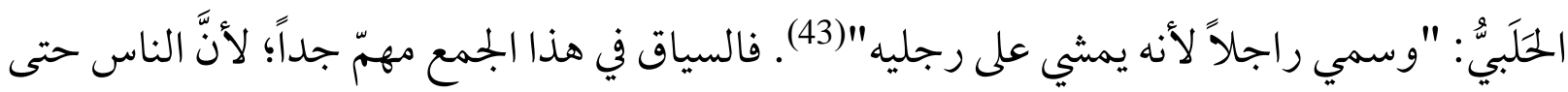


أهل العلم -أحيانَا يقعون في الأخطاء في تفسير الآية السابقة يظنون أنَّ القصدَ منه بَيء الرجال

$$
\text { الجنس من الذكر وليسَ بجيئهم بالمشي. }
$$

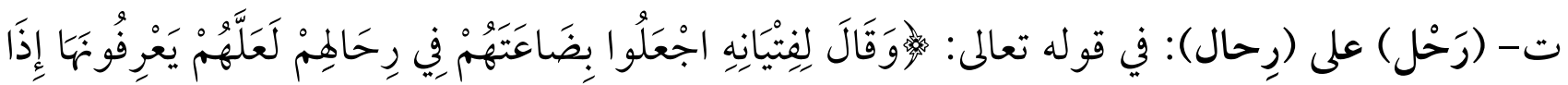

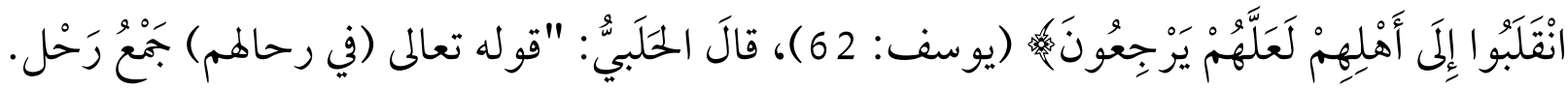

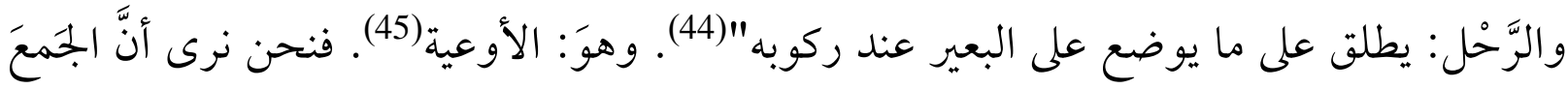

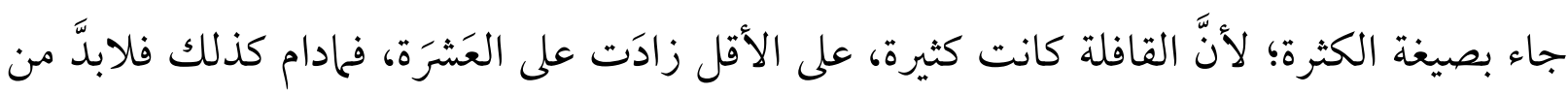

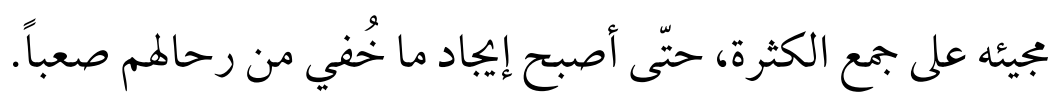

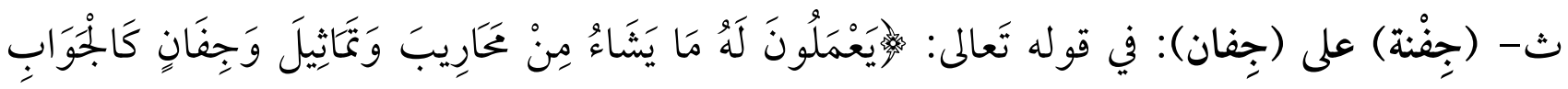

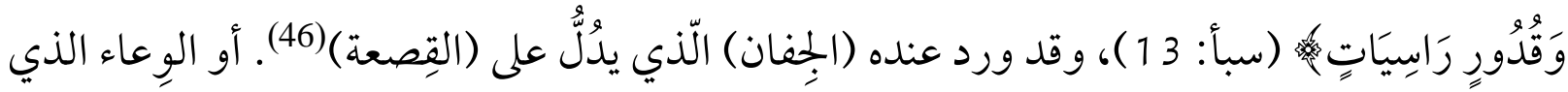

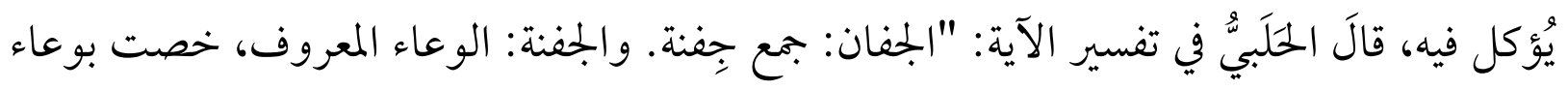

الطعام. ولتعارف العرب بمدحها ومدح من يطعم فيها خصها تعالى بالذكر في قوله تعالى: (وجفانٍ

$$
\text { كالجواب) جريًا على ما يألفونه ويتمدحون به"(47). }
$$

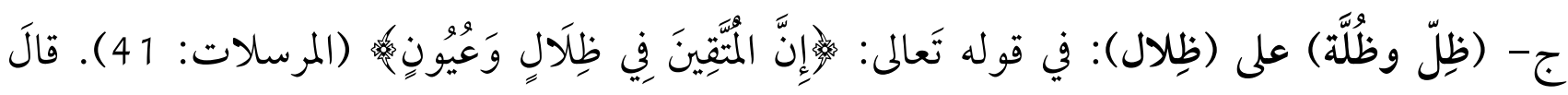

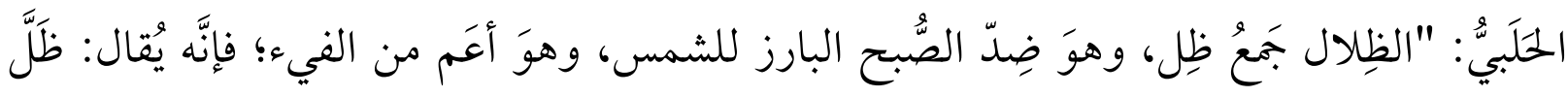

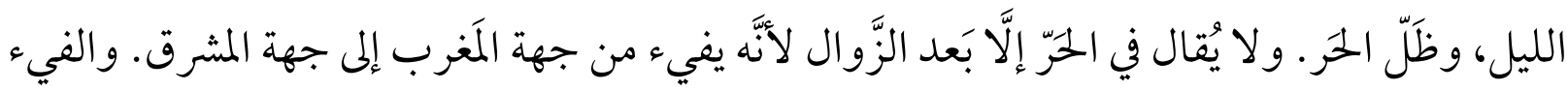

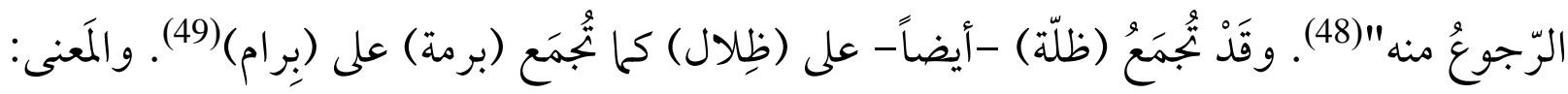

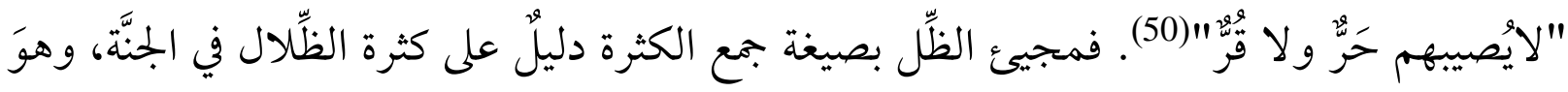

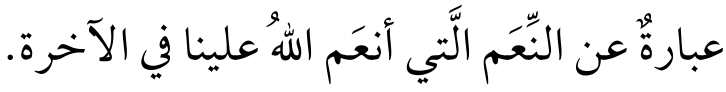

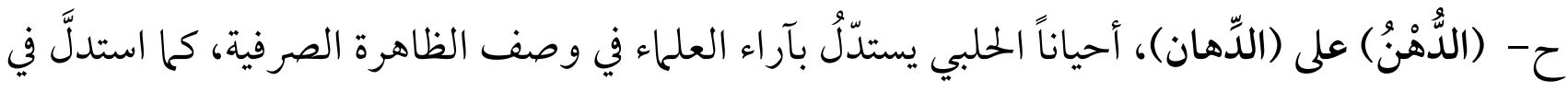

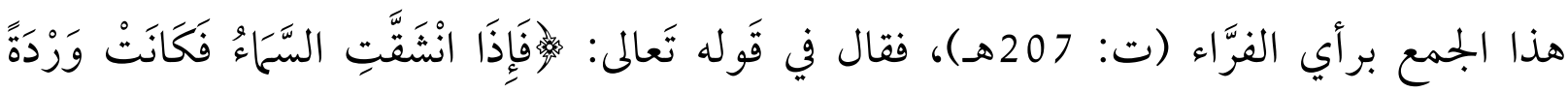

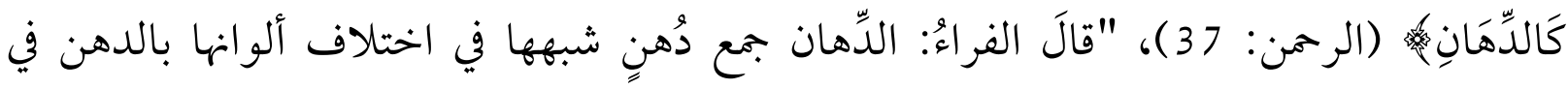


اختلاف ألوانه... وقيل: الدهان: الأديم الشديد الحمرة"(51). فالفَّاء لم يُصِِّح في جمع (الدهن) على أنه يأتي جمعه على (الدّهان)، بل اكتفى بذكر وصفه بالأديم الحمر فقط. قالَ الزجَّاج في تشبيه السماء

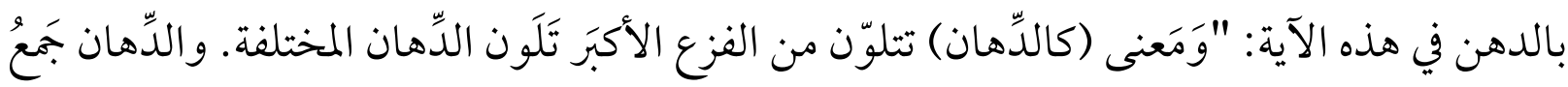

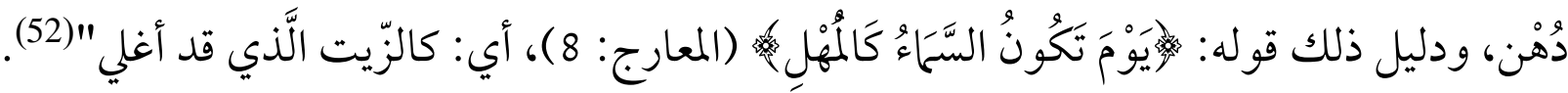
وهو: "ذائب الفضَّة و النحاس"(53).

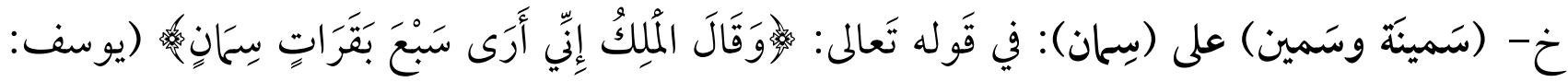
43). ذَكَرَ الحَلَبِّ أنَّ (سِمان) جمع (سمينة وسمين)، وشبَّهُه بـ(ظراف في ظريفةٍ وظريفِ). والسَّمْن: امتلاء الجمسد ضِدّ الهزَ ال. و السُّمْنَةُ: دواءُّ يتسمن به النساء) (54).

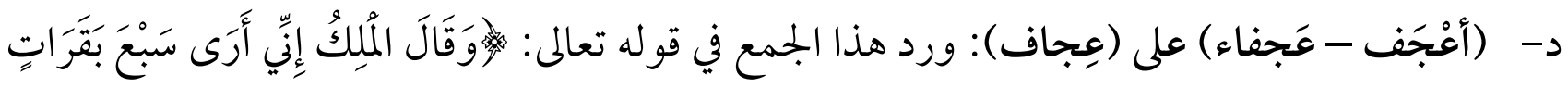

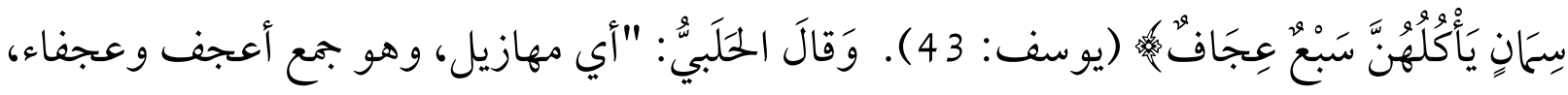
وهو الدقيق من المزال. و أصله من قولهم: نصل أعجف، أي دقيق. وأعجفَ الرَّجُل: صادفَ مواشَيَّ أو صارت عجافًا. وعجفتُ نفسي عن فلانٍ وعن الطَّعام، أي نَبت. وليس فِعال قياسًا لأفعل فعلاء ولا فعلاء أفعل، ولكن جمع فاعلٍ فعال لمقارنته بسمانٍ"(55). 5- صيغَة (فُعْلَة): وقد ورَدَت هذه الصيغة عند الحلبي، وهي:

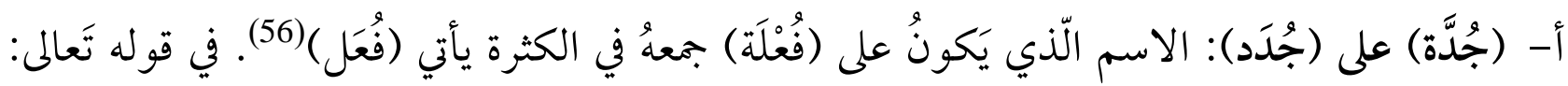

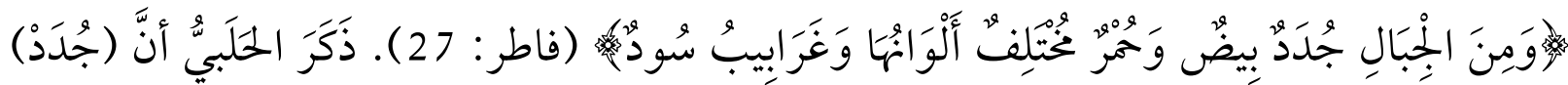
جمعُ (جُدَّة) وهي كل طريقِ في الجبل يخالف لونها لون ما يجاورها(57). وقالَ الأخفَش: "والجُدَدُ

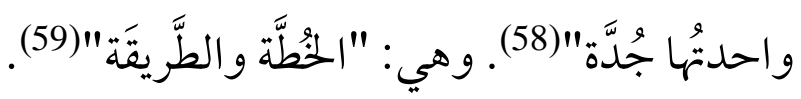

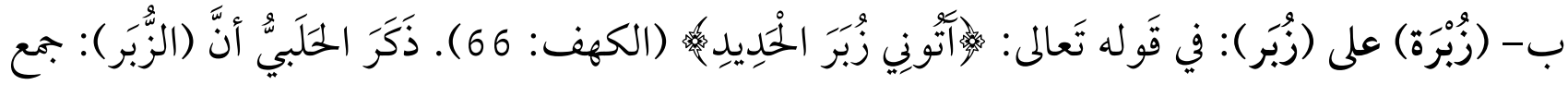
زُبْرَة، وهي القطعة العظيمة، ورجل أزبر أي عظيم الزبرة، وهي ما بين كتفي الأسد (60). فـ(زُبَر) جاءَ بصيغة جمع الكثرة؛ لأنَّ السَّد الَّذي بناه كانَ كبيراً جداً، فناسبَ الجمعُ عظمة السدّ - والله أعلم. 
6 - ميغَة (فَعَلَة): وَقَدَ وَرَدَتْ هذه الصيغة عند الحلبي، وهي:

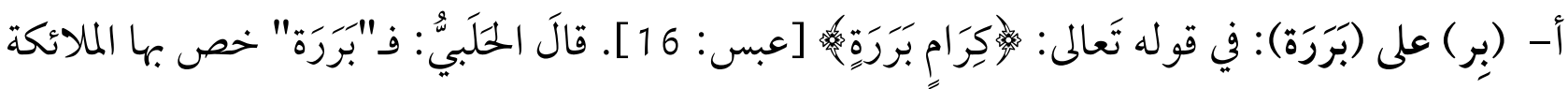
في القرآن من حيث إنه أبلغ من "أبرار" فإنه جمع بِر، وهو أبِلغ من "بارِ"، كما أن عَدْلاً أبَلَغ من عادلٍ. قلت: هذا بناء منه على أن "برًا" مصدر في الأصل وهو مسموع بل وصف بزنة فَعْلٍ كََعْبِ وضَخْمِ وَثَثَّ"(61). وقَد عَدَّ العلم)ء هذا الوزن من الأوزان السماعية، كما ورد في شرح التصريح على التوضيح،

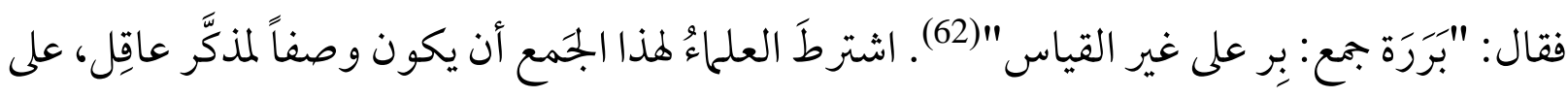
وزن (فاعل) صحيح اللام(63)؛ لكن المقصود من (بَرَرَة) حسب ما ذهبَ إليه الحلبيُّ هو (الملائكة)، ولا يُعلم جنس الملائكة، ولم يحدد جنسهم. ب- (سافِر ) على (سَفَرة): في قوله تَعالى:

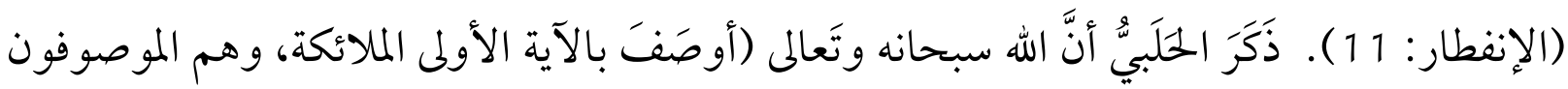
بالآية الثّانية (كراماً كاتبين). وهم جمع سافِرِ نحو كَتبَة في جَمَع كاتِبٍ)(64). 7 - صيغَة (فَعْلى): وما ورد عند الحلبي على هذه الصيغة، هي:

أ- (صَرِيع) على (صَرْعَى): هذا الوزن وردَعند العلماء وصفاً للناس لما يُبتلون به، وهوَ أشار إليه الخليل

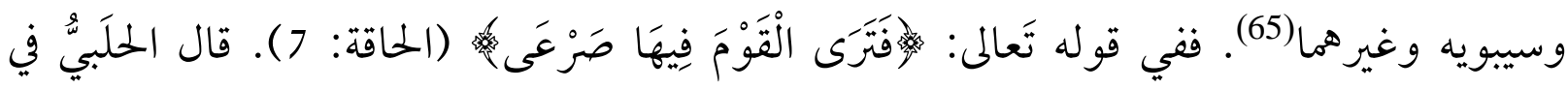

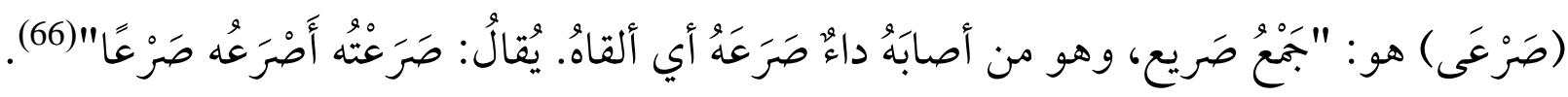
قال ابن عقيل : "صَرْعى بَمَعُ صَريع" (67).

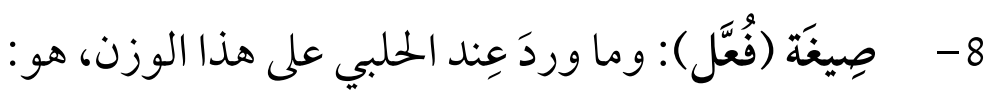

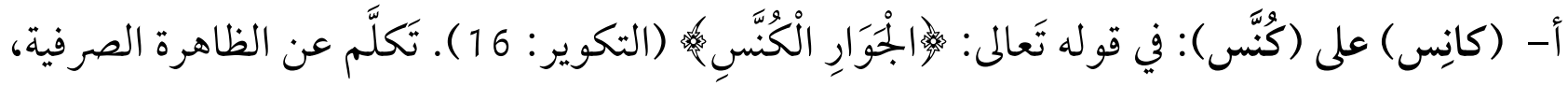
ويُفَسِّر ها تفسيراً دقيقاً، كما في تفسيره لهذه الآيَة، وهو يقول: "(كُنسّ) جمع "كانس، والكانس من الوحش ما دخل كناسه كالظبي وبقر الوحش، والمراد هنا النجوم؛ شبها في استتارها ببروجها بالوحش الداخل كناسه، وقد كنست كنوسًا"(68). وَقد يستَدلّ بقولٍ دون أن يُشير إلى قائله، كما في 
تفسيره هذا وهو استدلَّ بِقولِ الفََّّاء (ت 207هـ) حيثُ قالَ: "قيل: هي من الكواكب خمس: زحل والمريخ والمشتري وعطارد والزهرة. وقيل: كل كوكبٍ. وقد تقدم تفسير ذلك في قوله (الخنس)"(69).

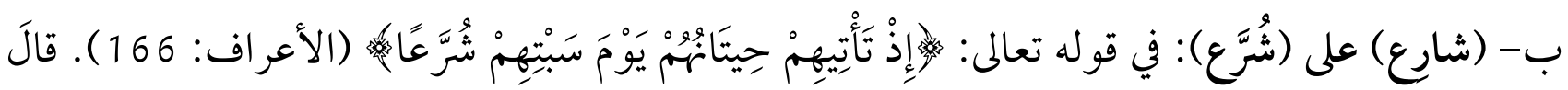

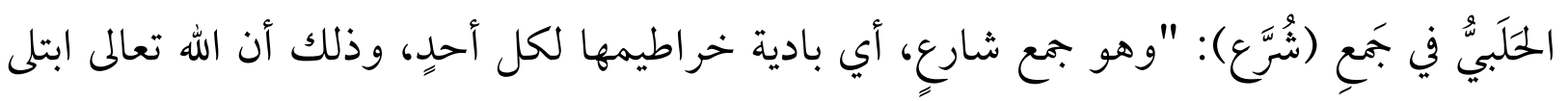
اليهود بتحريم الصيد يوم السبت وبإلهام السمكة بذلك، فكانت تظهر إلى أن يكاد الإنسان يقبضها، فإذا كانَ يَوْم الأحَد فحا بعده ذَهَبت حتَّى أعدوا حياضًا شارعةً إلى البَحْرِ بِجَداول"(70). وقد وردَ معنى (شُرَّع) في كِتاب الأفعال بمَعنى: "رافعة رؤوسها من قولهم: شرعت الشئ: إذا رفعته جدّا، وقال

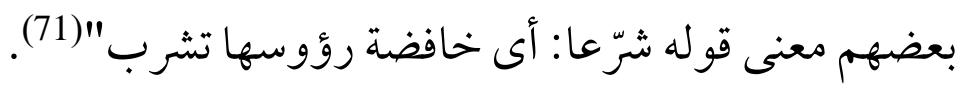
9- صيغَة (فِعْلان): وما وردَعند الحلبي على هذا الوزن، هو: أ- (صِنْو) على (صِنوان): أشار الحلبي إلى أن (صِنْو) يُجمع على (صِنوان) في الجمَع، دونَ أن يُشير إلى تحديد نوع الجَمعِ، فقال: "وصِنوانٌ في الجمَع"(72). لكن عندما يَذكر مسألة جمع التكسير، يَمَعَع (صِنو) في الكَثرةِ على غَيرِ (فِعلان)، كما قال: "ويجمع الصِنو أيضًا في القلة علي أَصِنَّة، وفي الكثرة على

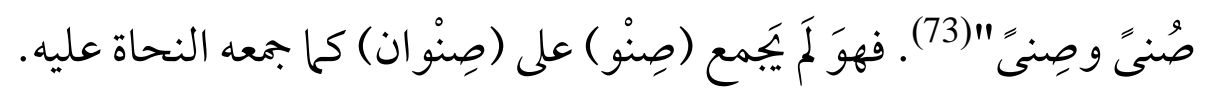

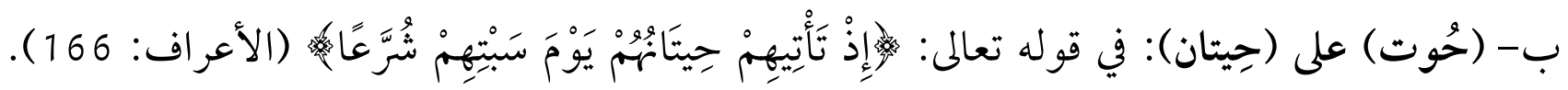
أوردَ الحَلَبُِّ رأي الفرَّاء (ت 207هـ) في جمع (حوت) على (حِيتان)، فقالَ: "قال الفراء: العرب تجمع الحوت: أحوتة وأحواتًا في القليل، فإذا كثرت فهي الحيتان"(74). ثَُّّ فَصَّل في تحليل هذا الجمعع، حيثُ

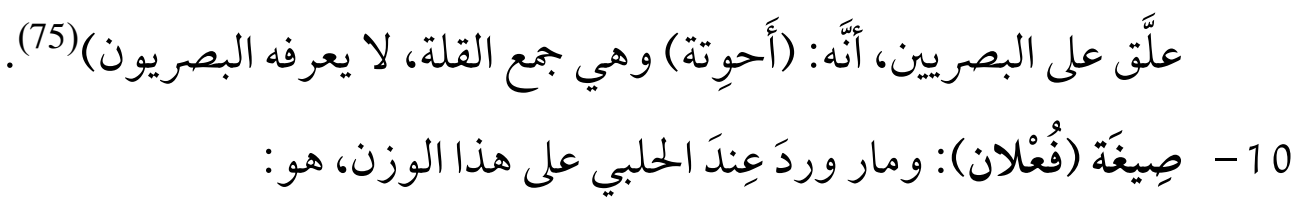
أ- (رهابين - وَرهابِنة) على (رُهبان): بها انَّ الوزن وَرَدَ عند العلمهاء جَنعاً لـفَفْل)، و(فَعَل)، و (فِعِيل)(76)، لكن من خلال اطّلاعنا في تفسير (العُمدة) ما رأينا وروده عند الحلبيّ هذا الوزن هو

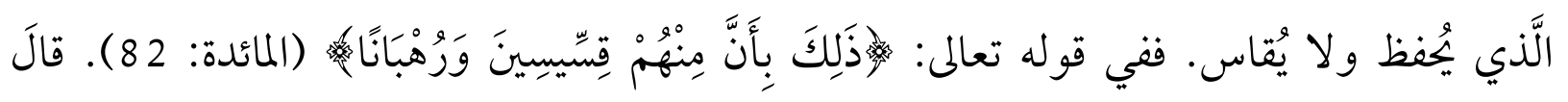




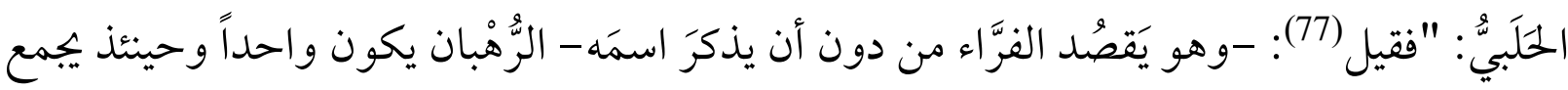

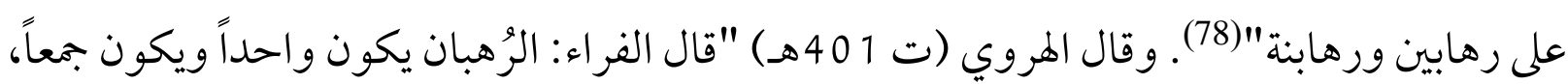

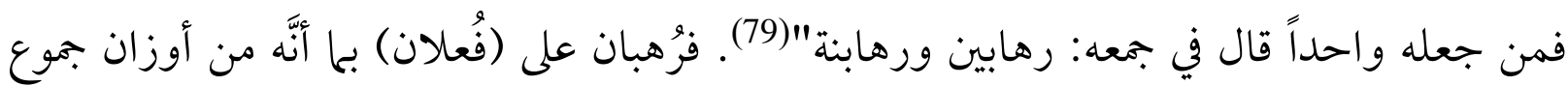
الكثرة، لكن عند الحلبيّ يُطلَقُ على الو احد أيضاً. 11 - 11

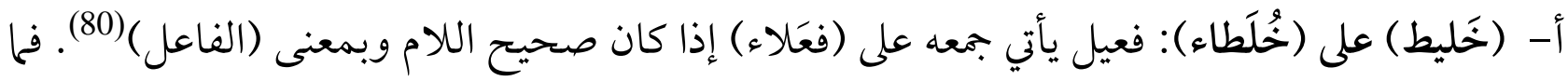

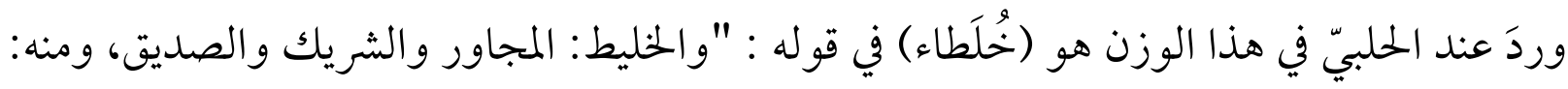

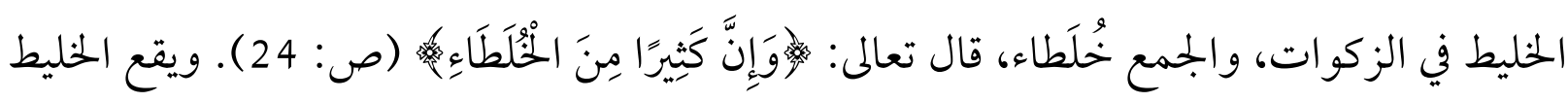
للو احد فأكثر "(81).

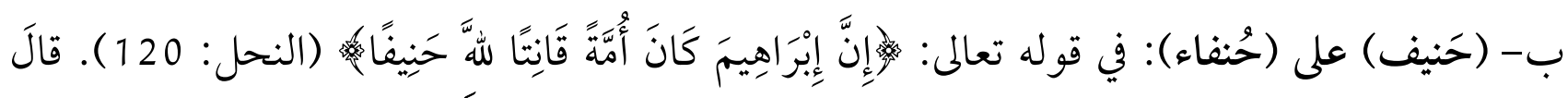

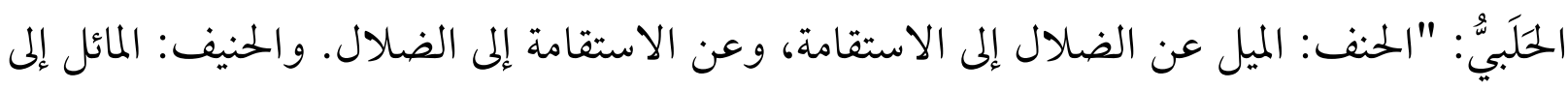

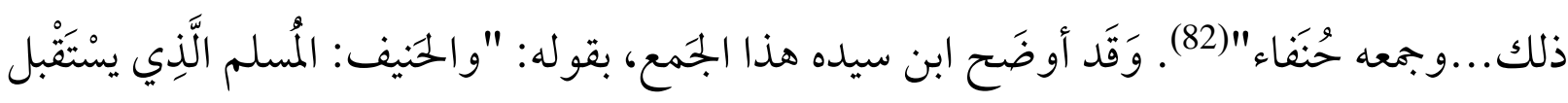

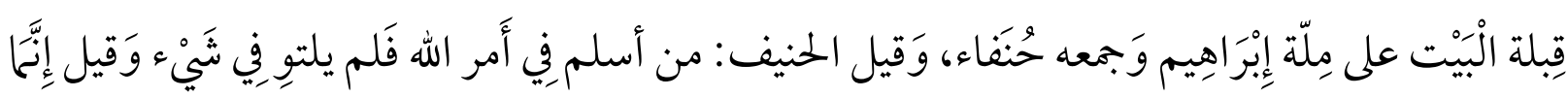

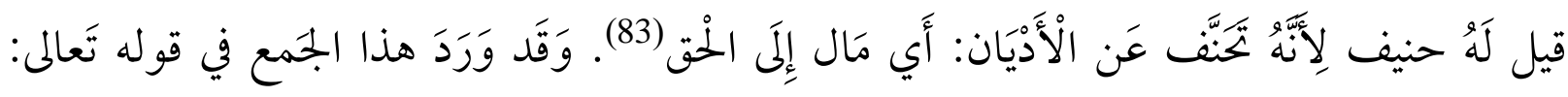

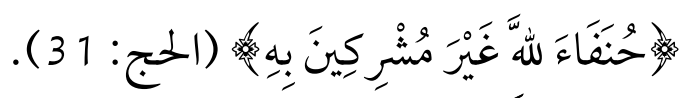

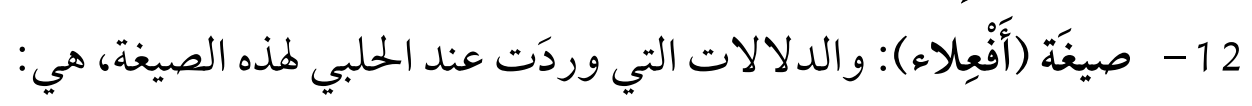

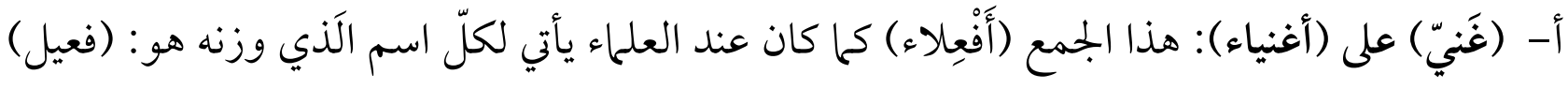

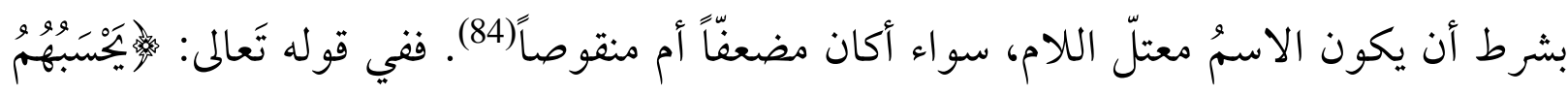

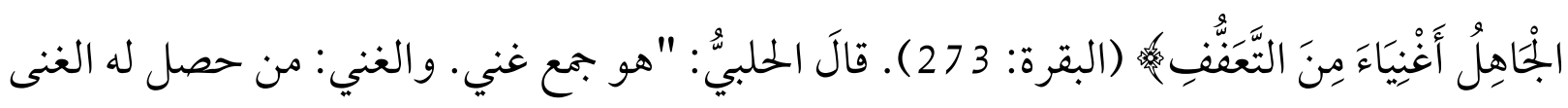
ضد الفقر"(85). 


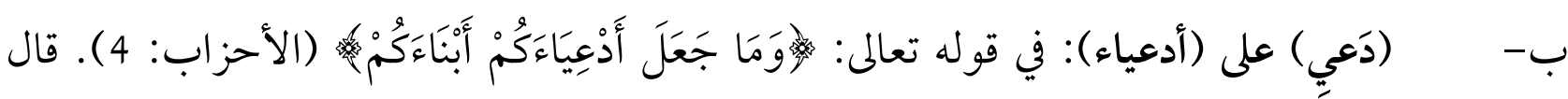

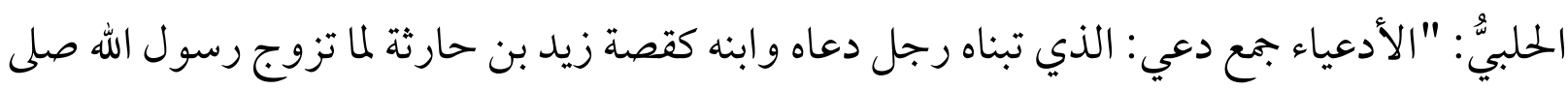
الله عليه وسلم امر أته زينب، فقال المشركون والمنافقون: كيف تزوج امر أة ابنه؟ فنفى الله ذلك عنه صلى الله عليه وسلم"(86).

أبنية جموع الكثرة كانت محلّ اهتحام عند الحلَبِيّ، فاهتََّّ بها كثيراً، وذلك للدلالات والمعاني التَّي تُستنبط

مرَّات يُفسّر ويُحلّل الآية دون الإشارة إلى من سبقهُ في تفسيرها، وأحياناً يُفصّل ويُو رد أقو ال العلماء من

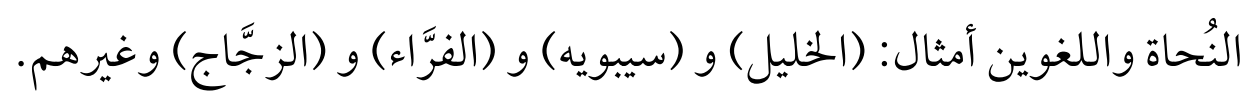

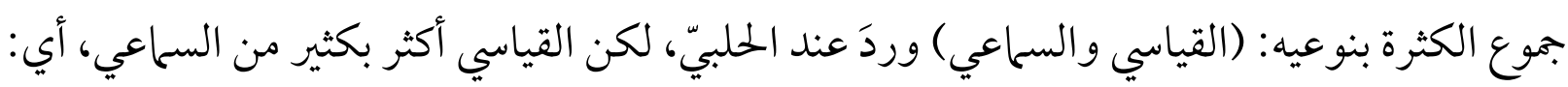

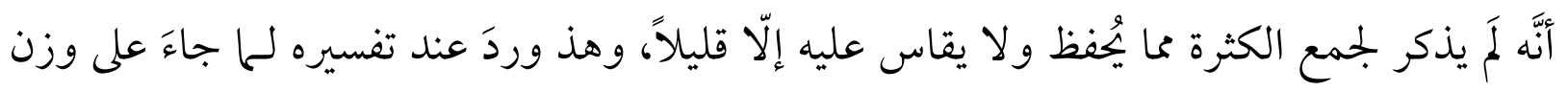

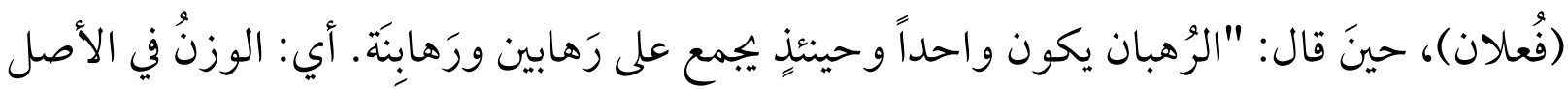
للجمَع، ولكن إذا أرادَ به المُفرد فجمعه: (رَهابين و رَهابينة).

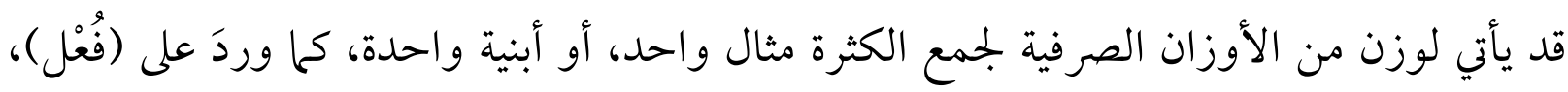

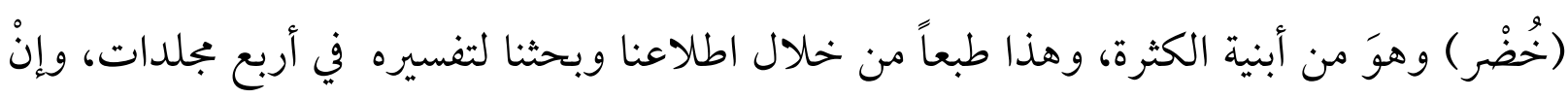
وُجدَت فيه أمثلة أخرى، فهذا قصور منَّا.

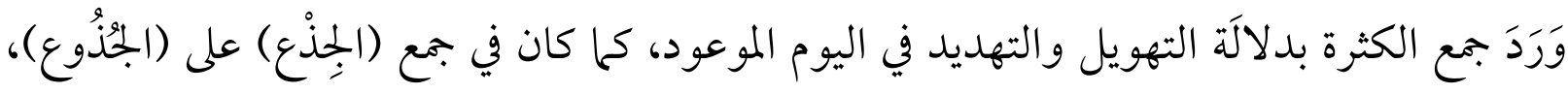

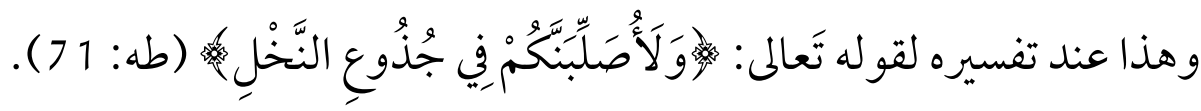
هُبَّه المتخيّل بالمحسوس، كما في تشبيه لنوعٍ من النبات برؤوس الشياطين. 
إذا احتاج الموقف إلى توضيحِ أكثر فعل ذلك، كما وَضََّحَ مسألة كيفية الإتيان إلى الحَج في قوله تعالى:

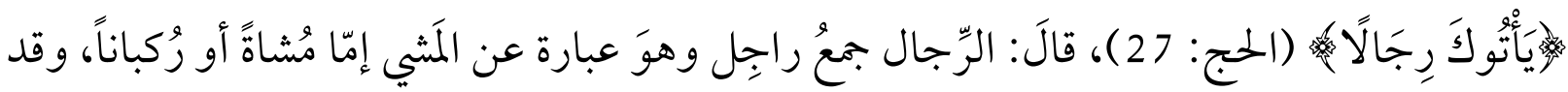
وقع الناسُ في الخَطَاً في فهم الآية أَنَ المُر اد برِجال جمع رَجُل. ما وردَ عند العُلماء في جمع (صِنْو) على (صِنْوان) كانَ عنده على غيره، فقالَ: يُجَمَعُ صِنْو على صُنى وَصِنَى في الكَثرة. ذكر المَدرستين (البصرة والكوفة) عنده واضح وظاهر، ففي مسألة صرفية بعد تحليلها وتفسيرها لغوياً يذكر رأيّ البصريين والكوفيين إذا احتاجت، ففي جمع (حُوت) على (أحْوِتَة) قالَ: قالَ الفرّاءُ: العرب تجمع الحوت : أحوِتَة وأحو اتاً في القليل، فإذا كثرت فهي الحِيتان، وأحوِتَة جمعُ لا يعرفه البصريون.

1. ابن الأثير: بحد الدين أبو السعادات المبارك بن محمد بن محمد بن محمد ابن عبدالكريم الشيباني الجزري ابن الأثير (ت:606ه)،

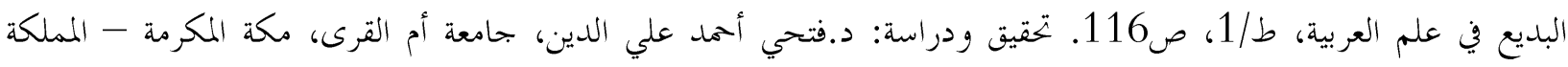

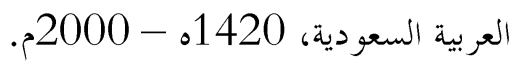

2. ابن الجزري: شمس الدين أبو الخير ابن الجزري، محمد بن محمد بن يوسف (ت:833ه)، شرح طيبة النشر في القراءات، ط/20،

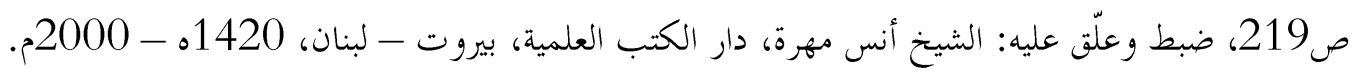

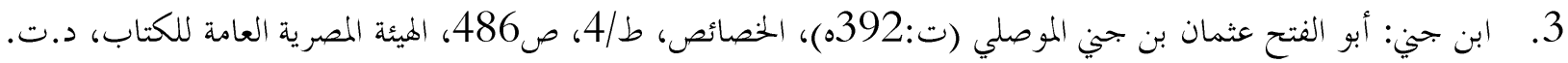

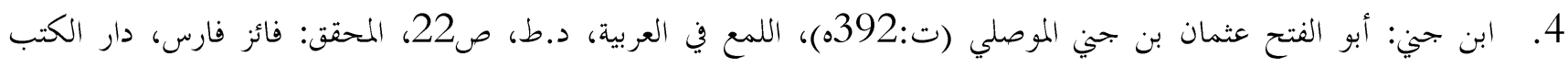

$$
\text { الثقافية، بيروت - لبنان، د.ت. }
$$

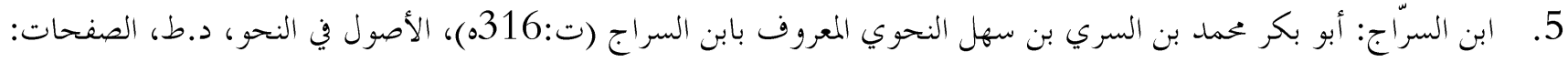

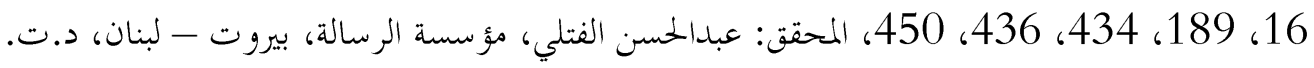

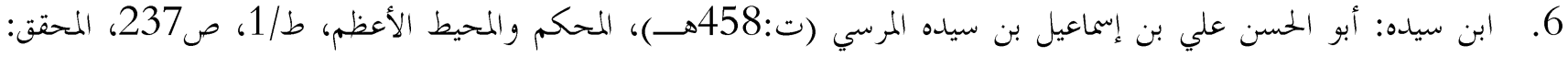

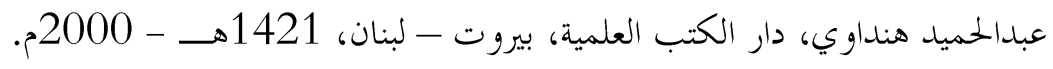

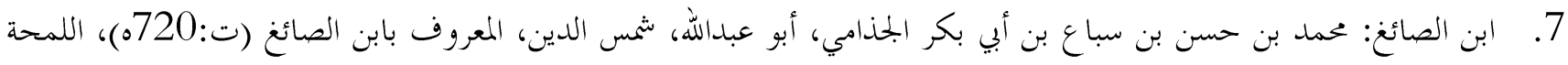

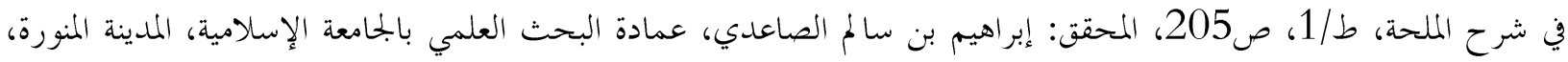

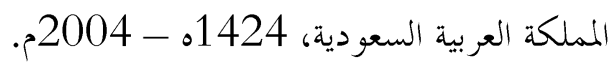


8. ابن عصفور: علي بن مؤمن بن محمد، الحضرمي الإشبيلي، أبو الحسن المعروف بابن عصفور (ت:669ه)، الممتع الكبير في

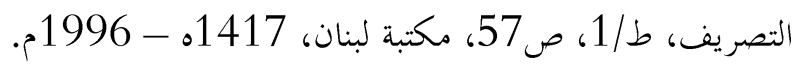

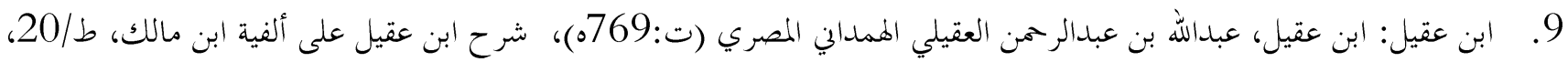

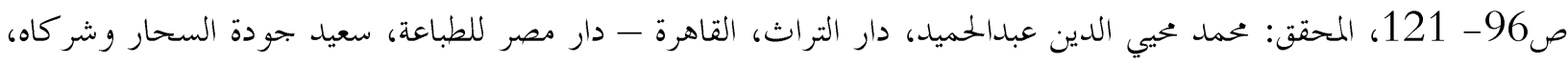
1980م، 1400

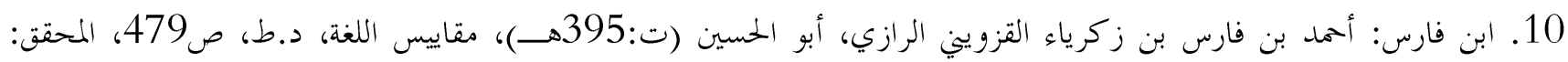

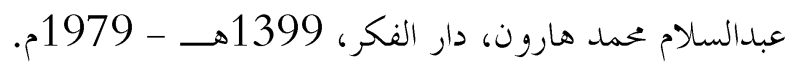

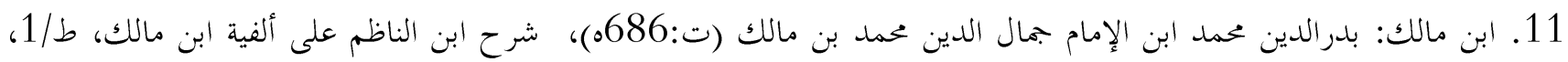

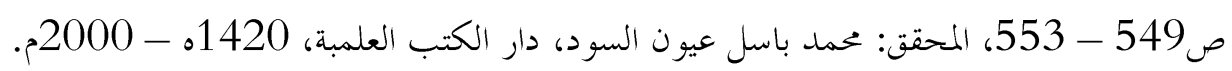

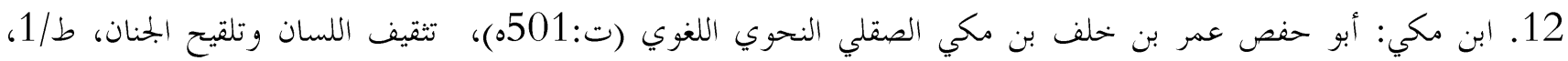

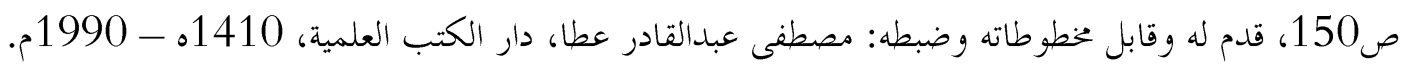

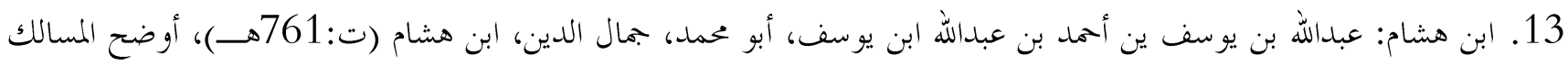

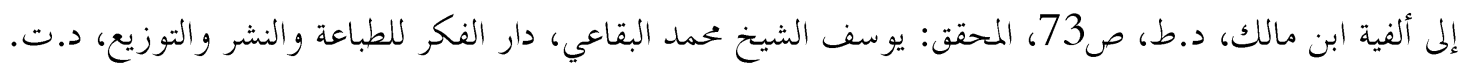

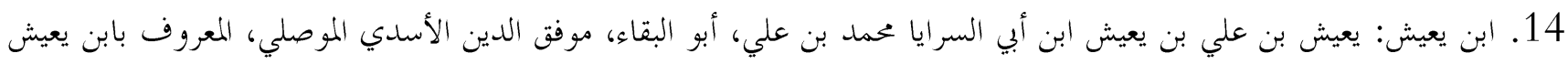

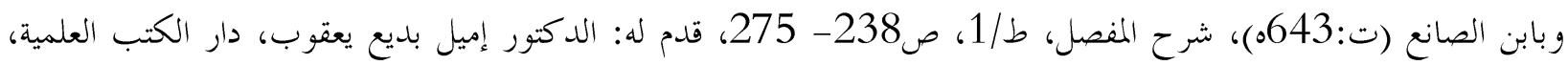

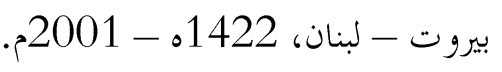

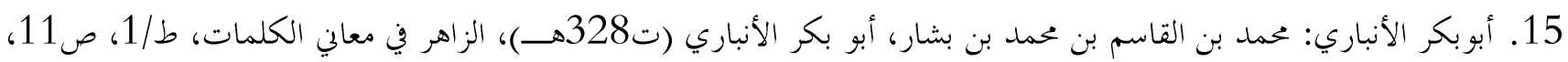

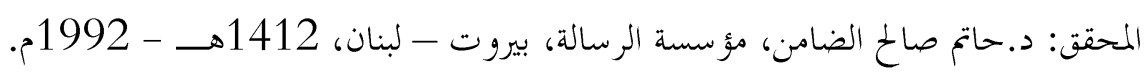

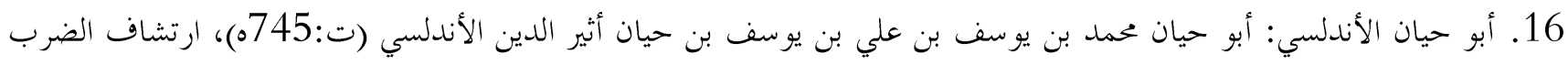

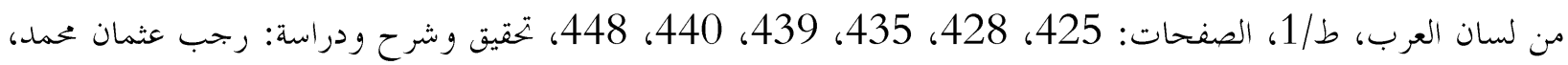

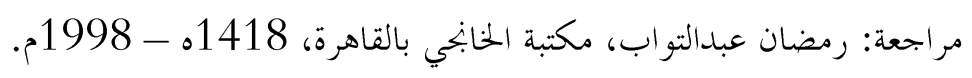

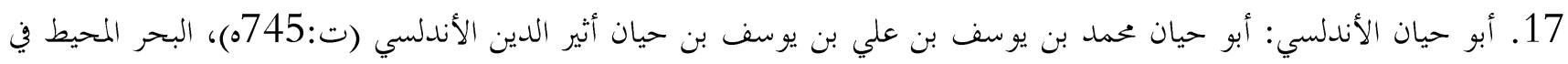

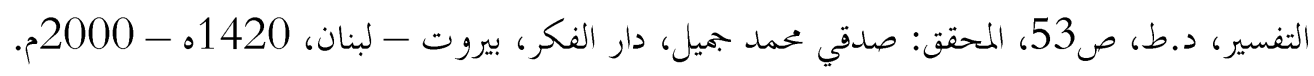

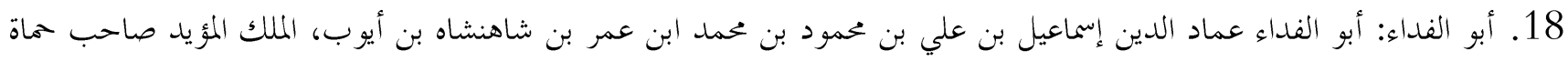

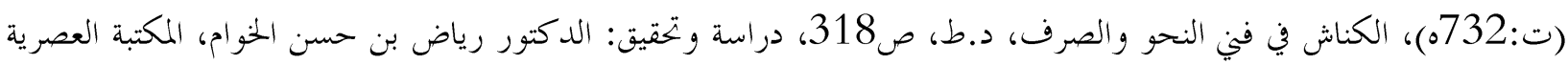

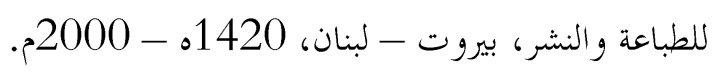

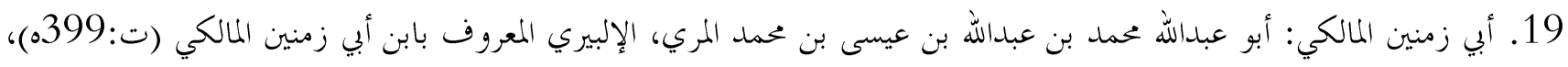

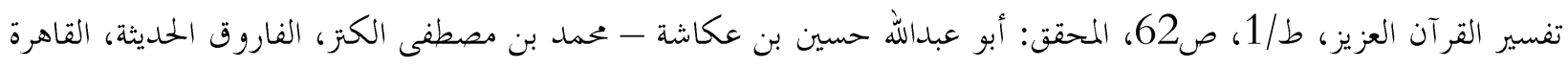

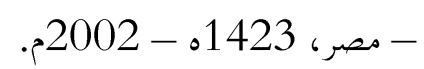


20. الأزهري: محمد بن أحمد بن الأزهري الهروي، أبو منصور (ت:370ه)، تذيب اللغة، ط/1، ص39- 307، المحقق: محمد

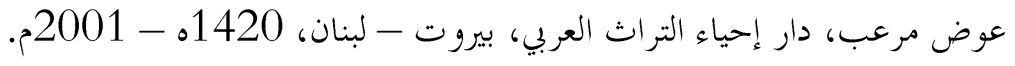

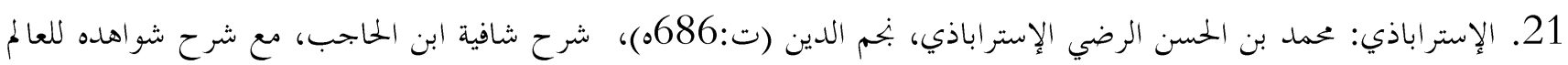

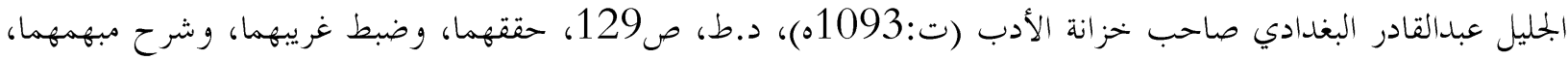

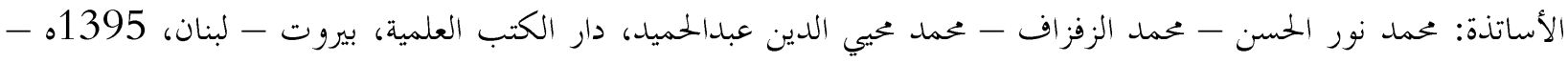

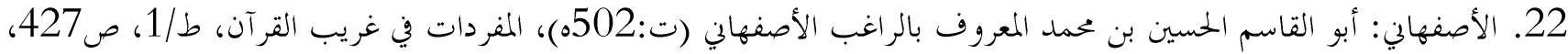

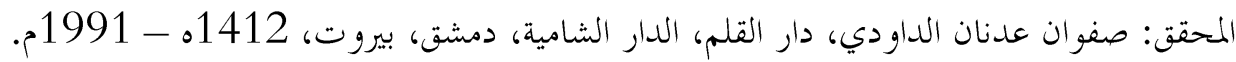

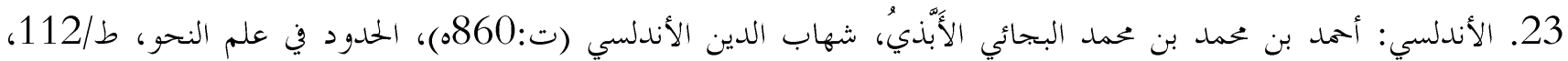

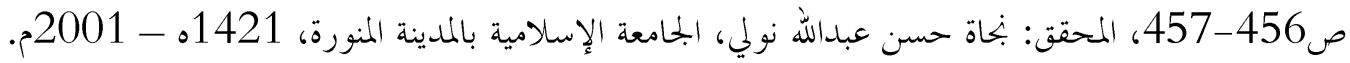

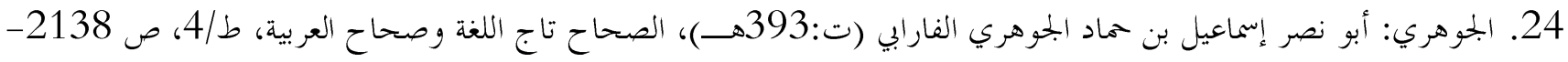

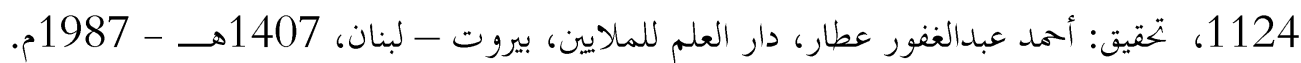

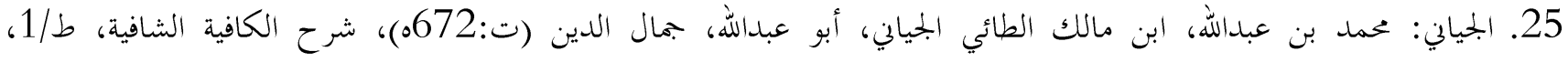

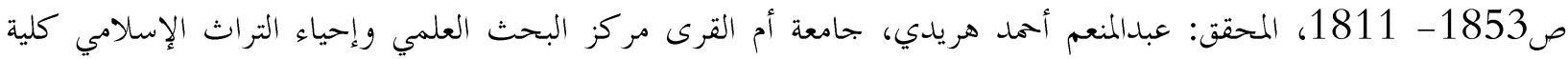
الشريعة والدراسات الإسلامية مكة المكرمة، د.ت.

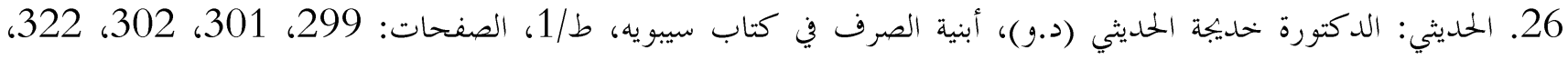

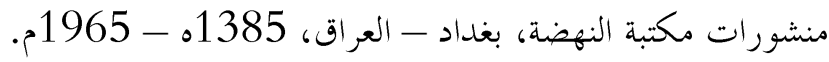

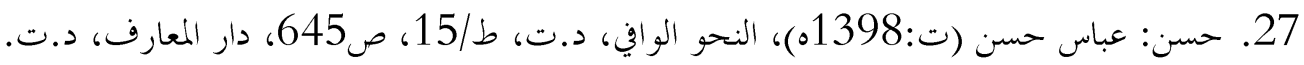

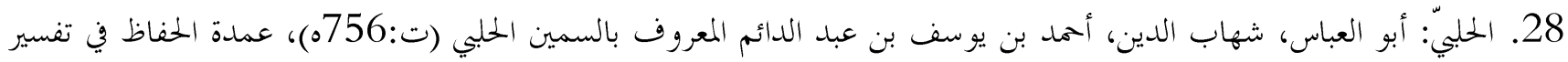

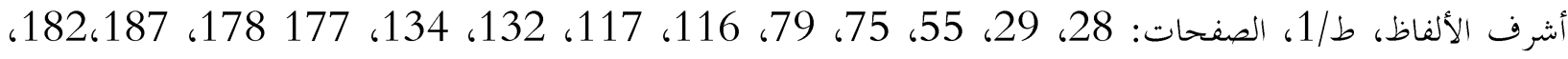

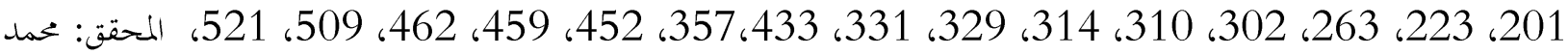
باسل عيون السود، دار الكتب العلمية، 1417هـ 263، - 1996، 1996،

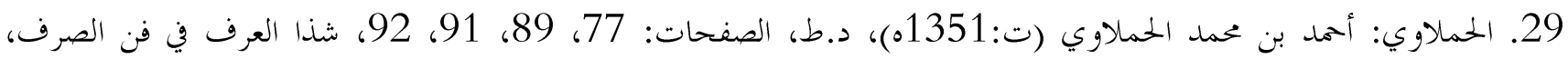

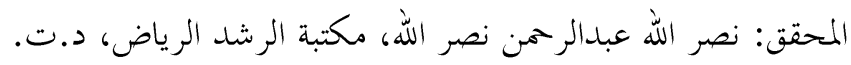

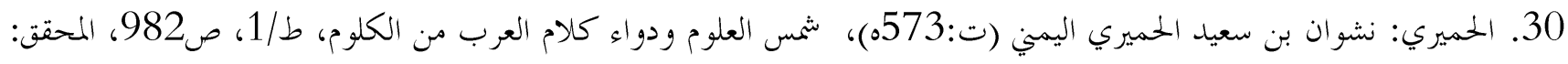

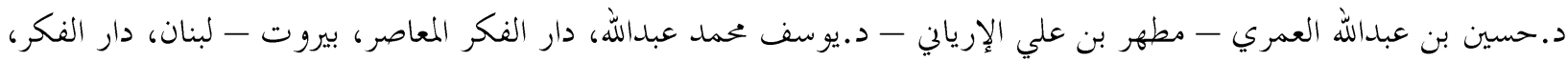

$$
\text { دمشق - سورية، 1420هـ - 1499 1999م. }
$$

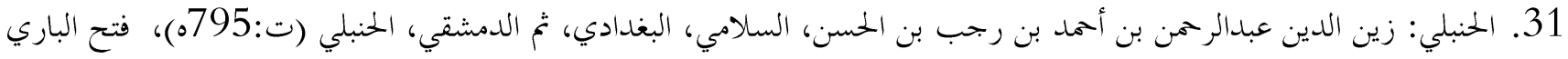

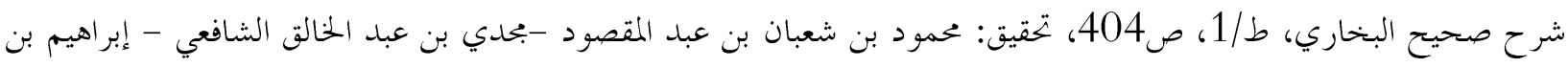
إسماعيل القاضي - السيد عزت المرسي - محمد بن عوض المنقوش - صلاح بن سالم المصراتي - علاء بن مصطفى بن همام - 
صبري بن عبد الخالق الشافعي، مكتبة الغرباء الأثرية، المدينة المنورة - السعودية، الحققوق: مكتب تحقيق دار الحرمين، القاهرة -

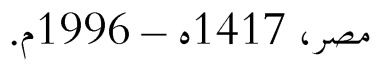

32. الزجاج: إبراهيم بن السري بن سهل، أبو إسحاق الزجاج (ت:311ه)، معاني القرآن وإعرابه، ط/1، ص101، 106-296، المحقق:

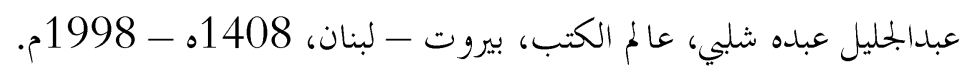

33. السرقسطي: سعد بن محمد المعافري القرطبي ثم السرقسطي، أبو عثمان، ويعرف بابن الحداد (ت:400ه)، كتاب الأفعال، د.ط، ص334، المحقق: حسين محمد محمد شرف، مراجعة: محمد مهدي علّام، مؤسسة دار الشعب للصحافة والطباعة والنشر، القاهرة

$$
\text { - جهمورية مصر العربية، 1395هـ - 1975م. }
$$

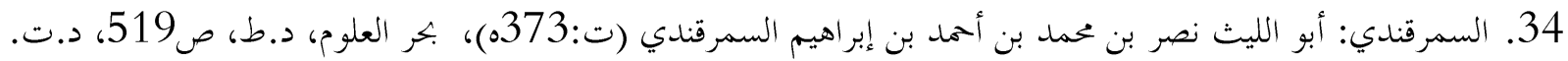

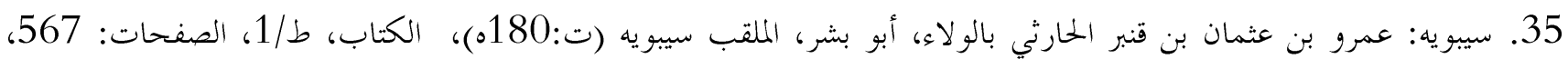

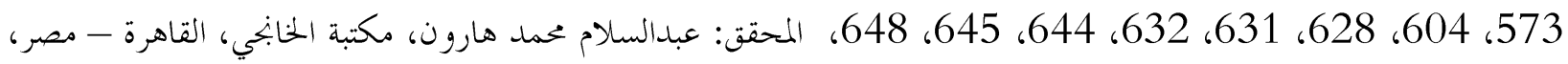

$$
\text { 1988- 1408 }
$$

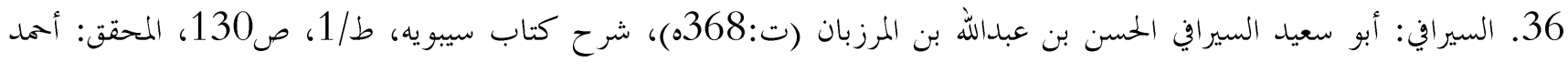

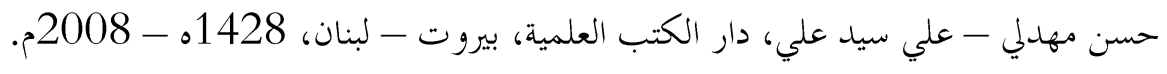

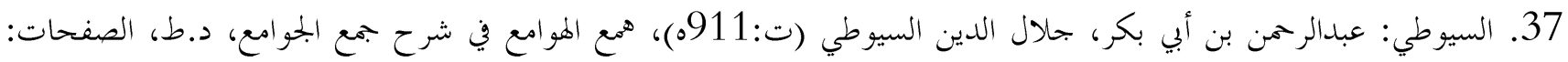

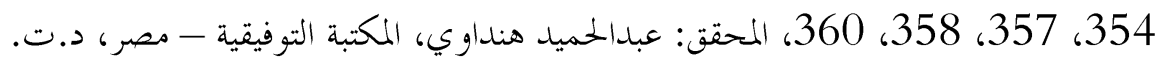

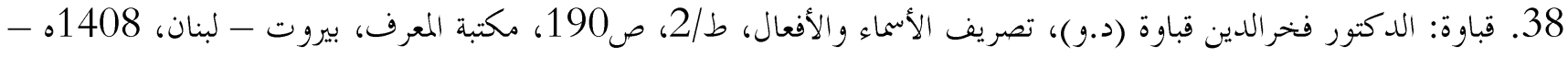

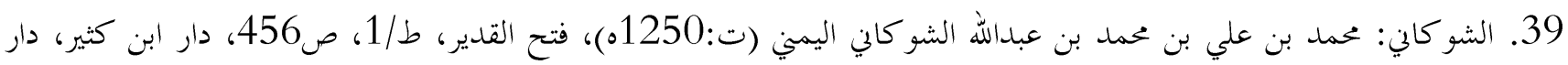

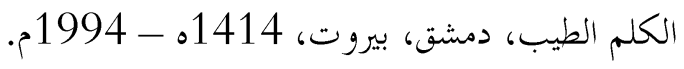

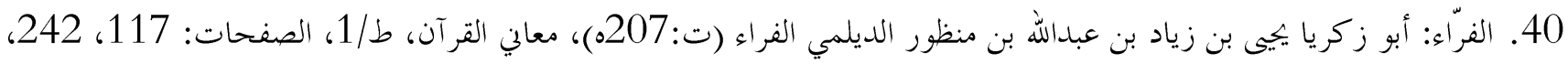

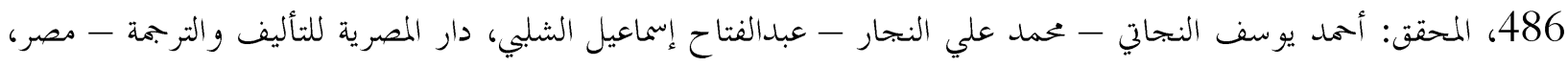

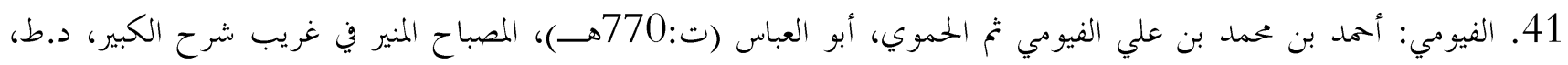

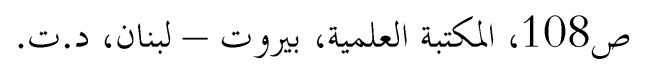

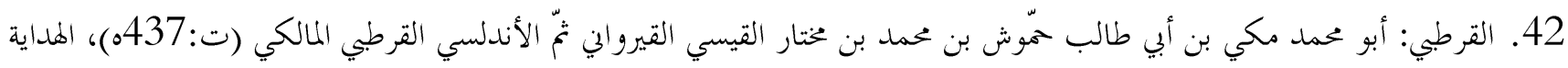

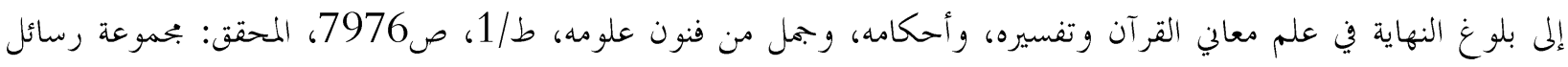

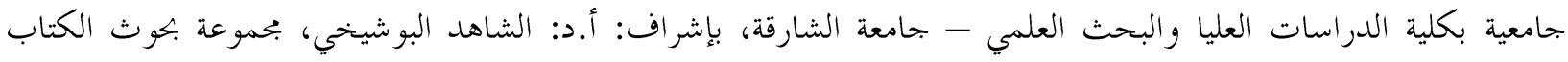

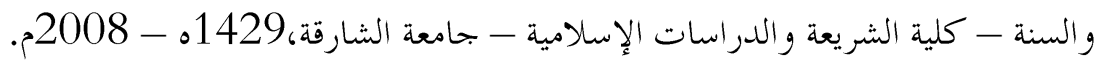




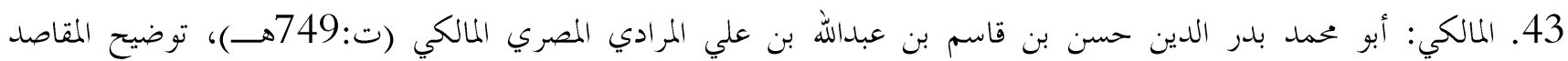
والمسالك بشرح ألفية ابن مالك، طالئ، الصفحات: 1377، 1383، 1380، 1390، شرح وتحقيق: عبدالرحمن علي سليمان، دار

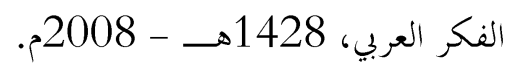

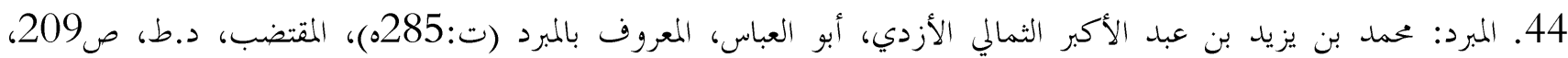

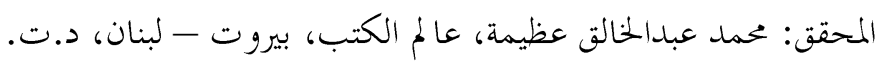

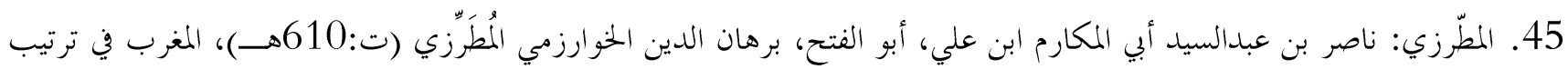

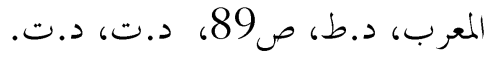

46. المكودي: أبو زيد عبدالرممن بن علي بن صالخ المكودي (ت:807هاهو)، شرح المكودي على الألفية في علمي النحو والصرف

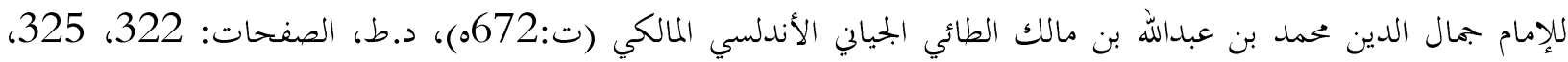

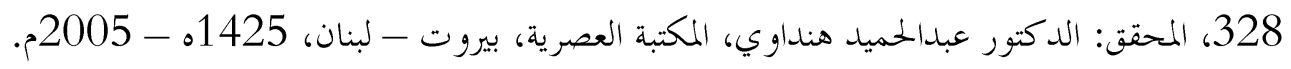

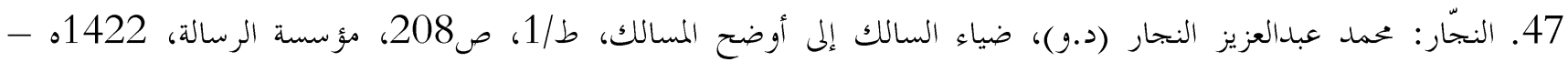

$$
\text { 2001 }
$$

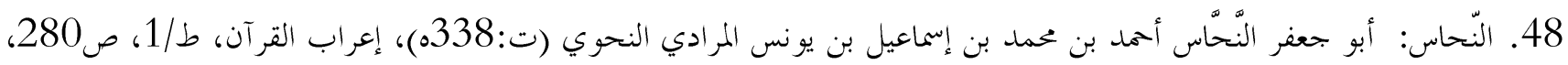

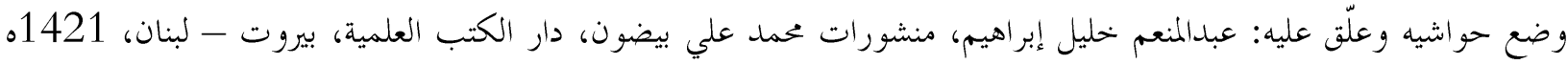

$$
\text { 2000- }
$$

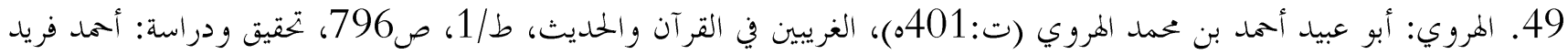

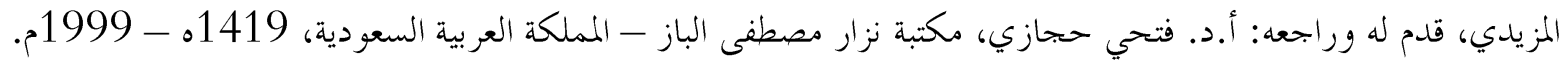

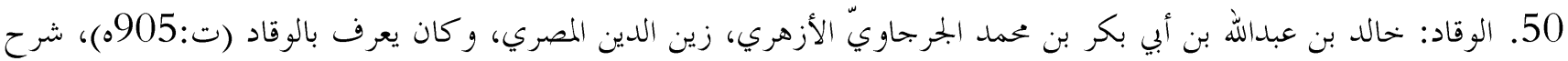

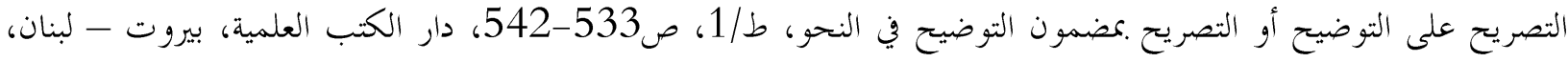

$$
\text { 2000- 1421 }
$$

$$
\text { (1) مقايس اللغة:479/1 }
$$

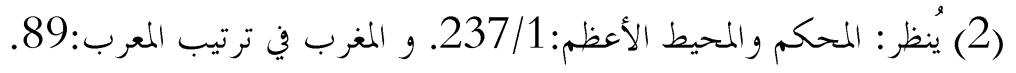

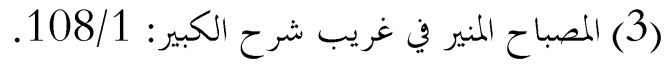

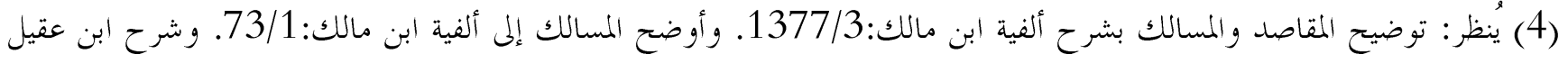

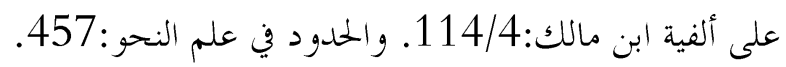

$$
\text { (5) تصريف الأسماء والأفعال:190. }
$$

(6) ينظر: شرح المكودي:322/1. والكناش في فين النحو والصرف:318/1. والكاءلمالمع في العربية:22. وشرح ابن عقيل على ألفية ابن

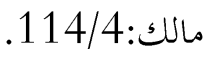




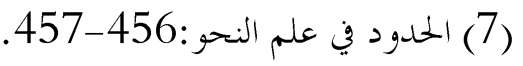

(8) المحة في شرح الملحة:205/1.

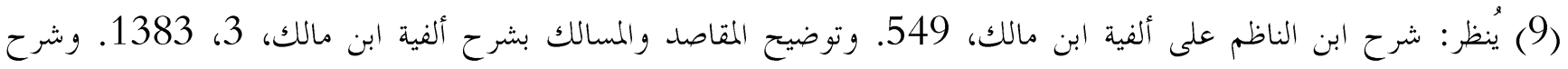
المكودي على الألفية في علمي النحو والصرف، 325.

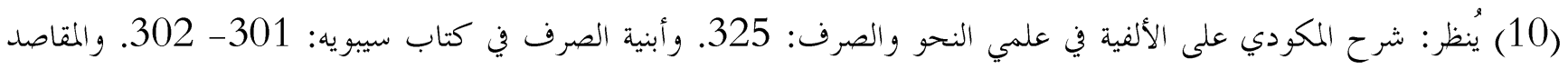

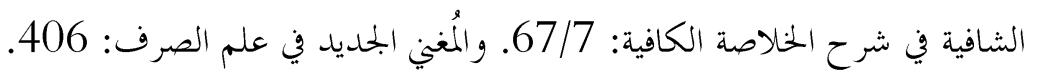

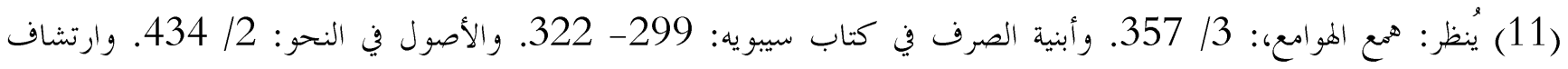

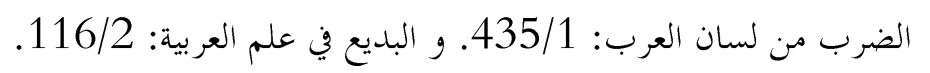

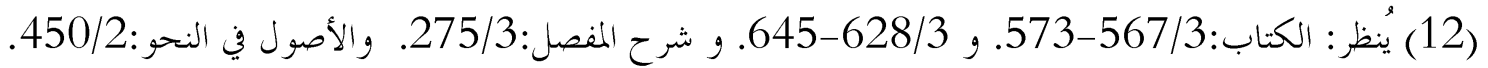

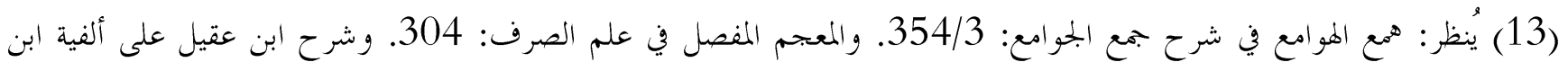

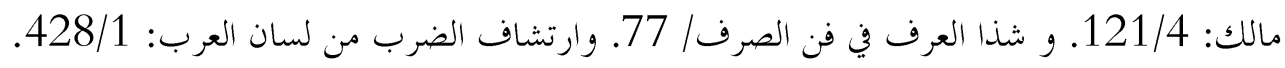

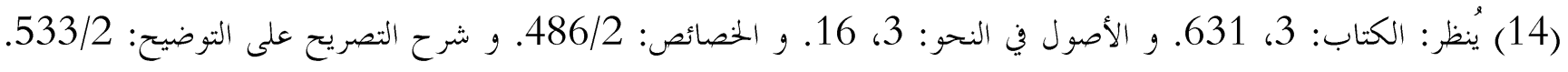

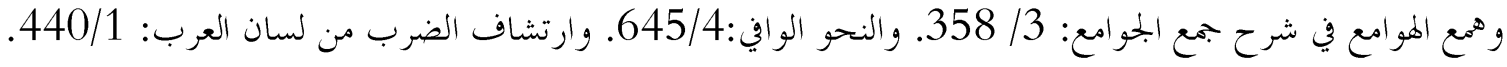

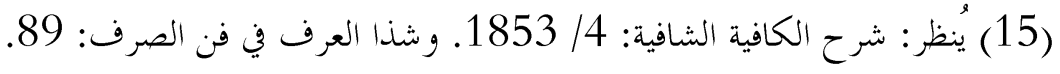
(16) الكتاب: 13 (15/ (15)

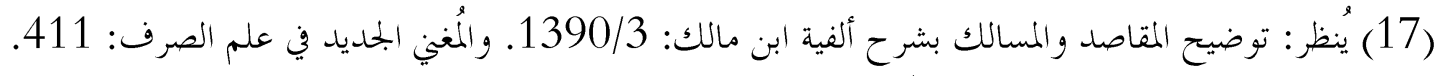

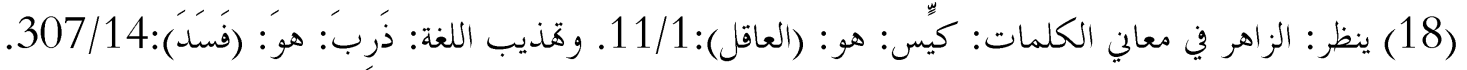

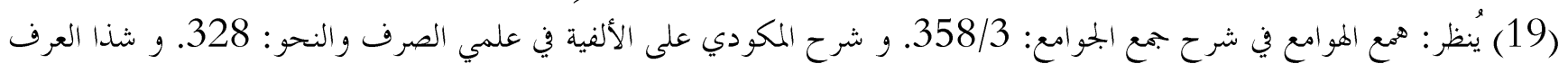
في فن الصرف: 89. وارتشاف الضرب من لسان العرب:

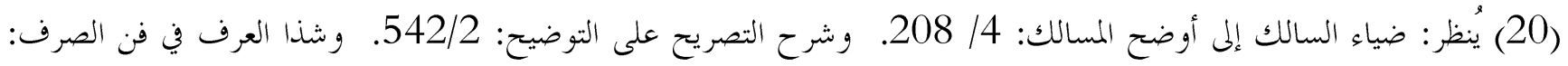

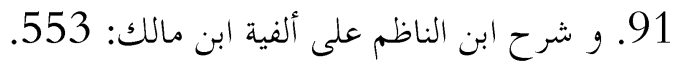

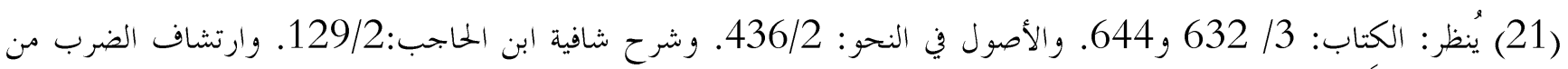
لسان العرب: 448/1.

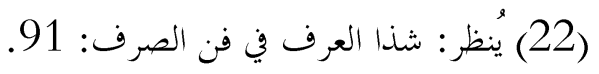

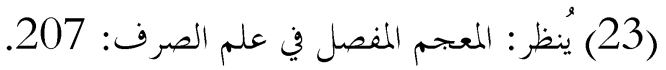

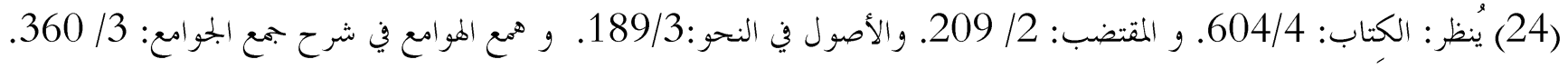
وشذا العرف في فن الصرف: 92. (25) يُنر: شرح ابن الناظم على ألفية ابن مالك، 549. و و و توضيح المقاصد والمسالك بشرح ألفية ابن مالك، 3، 1383. و شرح المكودي على الألفية في علمي النحو والصرف، 325. 
(26) عمدة الحفاظ في تفسير أشرف الألفاظ، 1، 509. وينظر: الحديث في:مصنف عبدالرزاق الصنعان:287/8.

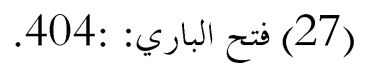

(28) يُنر: شرح المكودي على الألفية في علمي النحو والصرف: 325. وأبنية الصرف في كتاب سيبويه: 301 302 302.

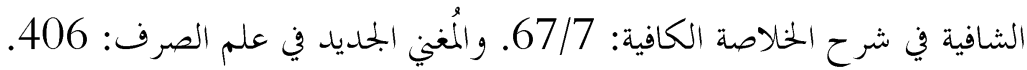

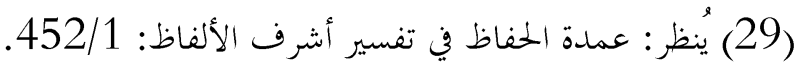

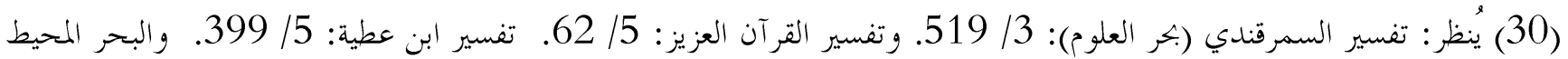

$$
\text { في التفسير: 53/7. }
$$

(31) يُظر: همع الهوامع،: 3/ 357. وأبنية الصرف في كتاب سيبويه: 299- 322. والأصول في النحو: 2/ / 434. 434. وارتشاف

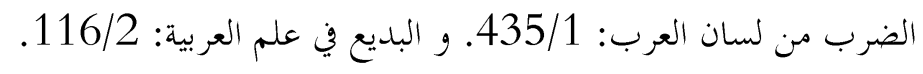

(32) ينظر: عمدة الحفاظ في تفسير أشرف الألفاظ: 132/1.

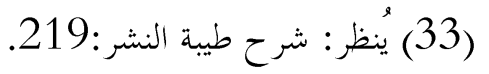

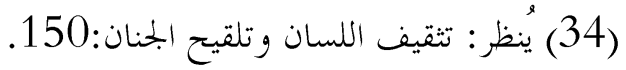

(35)عمدة الحفاظ في تفسير أشرف الألفاظ: 314/1)

(36) عمدة الحفاظ في تفسير أشرف الألفاظ: 55/2.

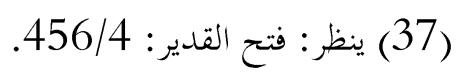

(38) عمدة الحفاظ في تفسير أشرف الألفاظ: 187/2.

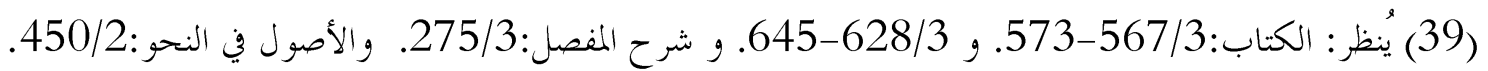

302/1 (40) عمدة الحفاظ في تفسير أشرف الألفاظ:

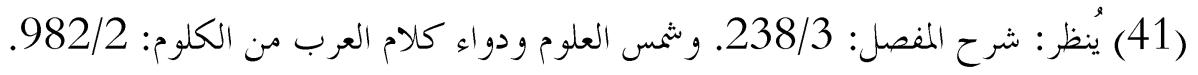

(42) عمدة الحفاظ في تفسير أشرف الألفاظ: 75/2.

$$
\text { 75/2 }
$$

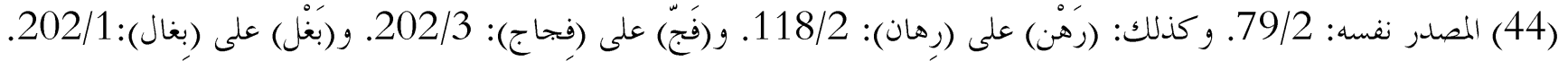

$$
\text { ور(نَقب) على (نقاب):211/4. }
$$

(45) ينظر: الكشاف عن حقائق غوامض التريل:235/5.

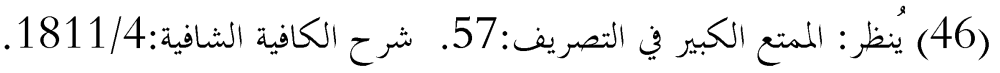

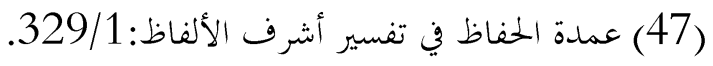

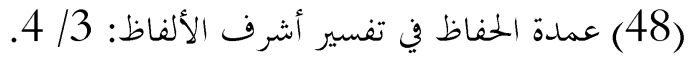

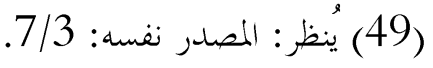

(50) الهداية إلى بلوغ النهاية:7976/12. 


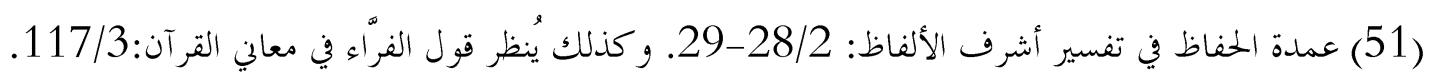

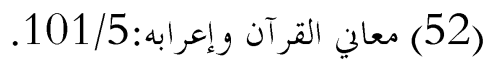

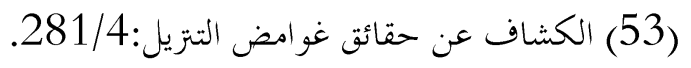

(54) عمدة الحفاظ في تفسير أشرف الألفاظ: 223/2. وينظر: المفردات في غريب القرآن: 427. والصحاح تاج اللغة وصحاح

$$
\text { العربية: 2138/5. }
$$

(55) عُمدة الحفاظ في تفسير أشرف الألفاظ: 32/3. ومادة: (عَشراء) على (عشار): 77/3.

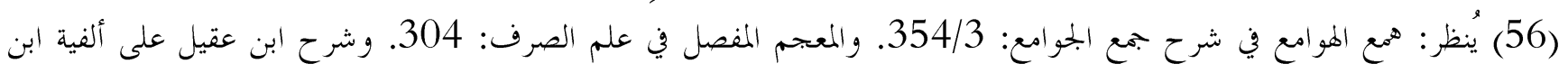

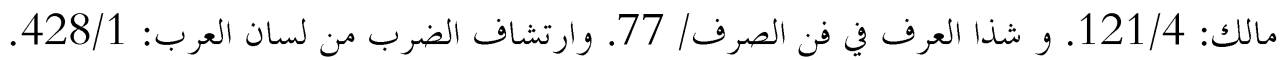

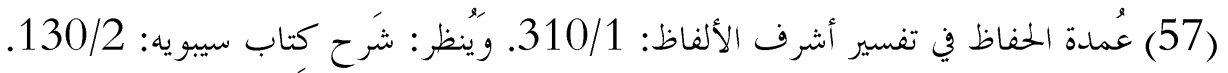

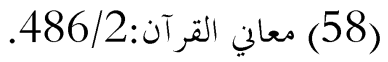

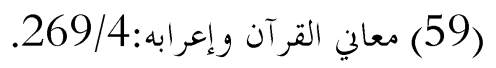

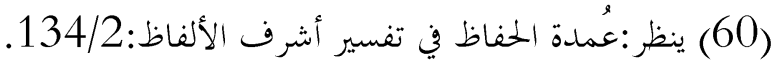

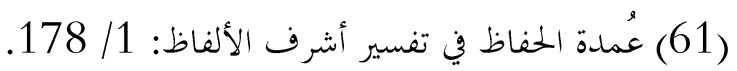

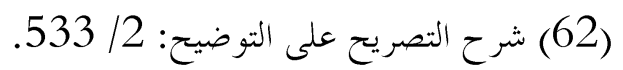

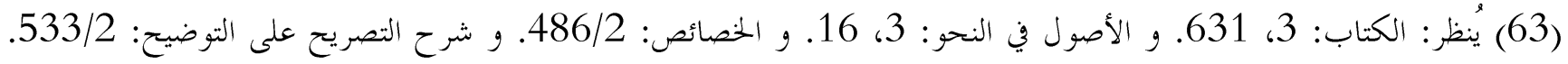

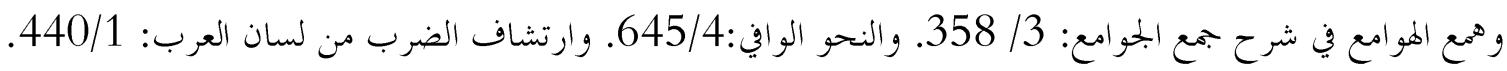

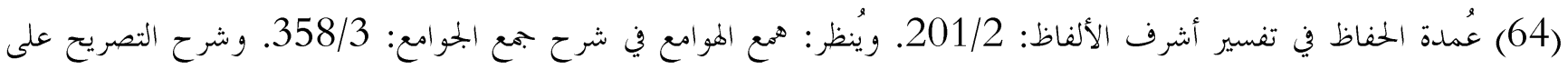
التوضيح: 533/2.

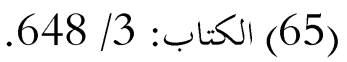
(66) عُمدة الحفاظ في تفسير أشرف الألفاظ: 2 / 331. (67) شرح ابن عقيل على ألفية ابن مالك:96/4)

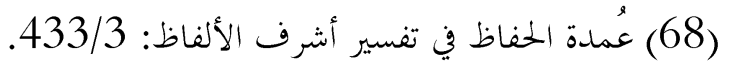

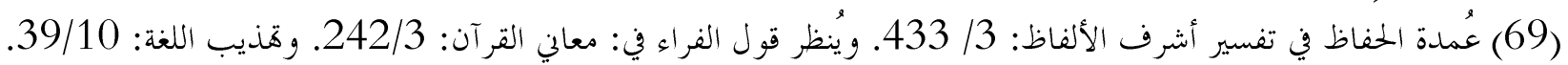

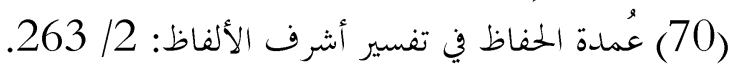

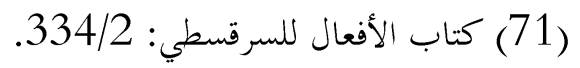

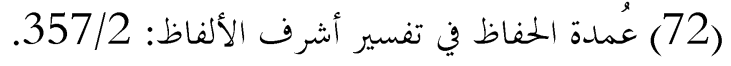

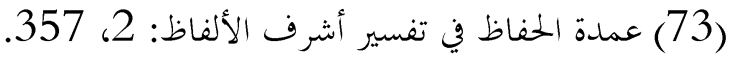

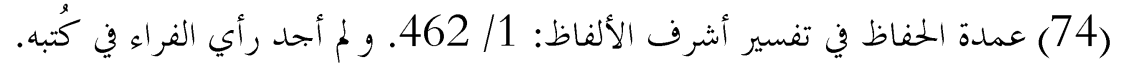
(75) يُنظر: المصدر نفسه: 
(76) يُظر: الكتاب: 632/ 632 و 644. والأصول في النحو: 436/2. و شرح شافية ابن الحاجب:129/2. وارتشاف الضرب من

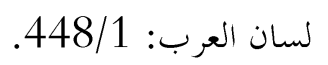

(77) يُنظر قول الفراء في: إعراب القرآن للنحاس: 280. والنحاس جمَعَ (رُهبان) من (راهب) كما ورد عند أغلب النحاة بأنه يميمع

(راهبب) على (رُهبان).

178) عُمدة الحفاظ في تفسير أشرف الألفاظ: 116/2.

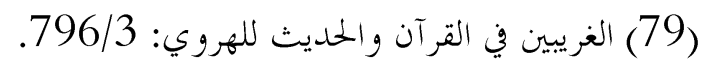

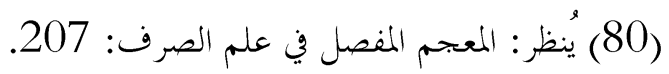

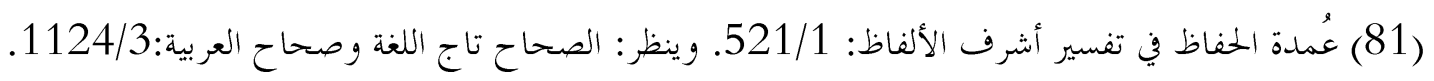

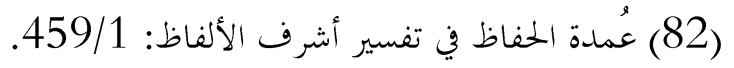

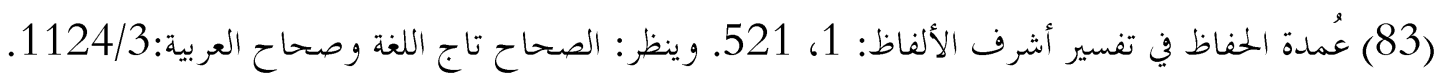

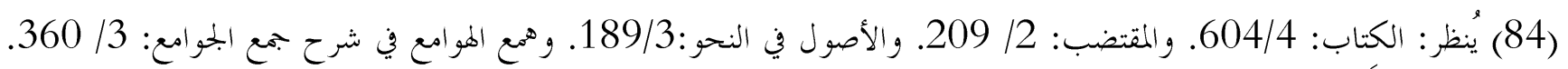

$$
\text { وشذا العرف في فن الصرف: } 92 .
$$

(85) عُمدة الحفاظ في تفسير أشرف الألفاظ: 177/3.

(86) المصدر نفسه: 16/2. 